\title{
A Case for the Twenty-First Century Constitutional Canon: Schneiderman v. United States
}

\author{
DAVID FONTANA*
}

\section{INTRODUCTION}

Hidden in the basements of American law libraries and in the Westlaw and Lexis databases is a generally ignored 1943 case, Schneiderman v. United States. ${ }^{1}$ Schneiderman is a case of substantial importance and interest that has belonged in the constitutional canon for some time. In Schneiderman, the Supreme Court of the United States blocked the government's attempt to denaturalize an American citizen, a leader of the Communist Party, because the Court found that Communists could be "attached to the principles of the Constitution." 2 The Court also announced a new, relatively high evidentiary burden that the government has to meet in order to strip naturalized citizens of their citizenship. ${ }^{3}$

Schneiderman is of even greater importance after September 11, 2001, because it sheds light on several key issues facing both this country and its law students and lawyers. September 11, 2001 was a monumental day in American history, politics, culture, and law. The after-effects of that day have just begun to trickle into university classrooms across the country. There are many reports of course offerings that address topics related to September 11. For instance, immediately after September 11, the Univer-

${ }^{*}$ D.Phil. expected, Oxford University, 2004; J.D. expected, Yale University, 2004; B.A., University of Virginia, 1999. Many thanks to the following individuals for their assistance with this project and for their comments on all or part of the ideas in this Article: Bruce A. Ackerman, Morris S. Arnold, Guido Calabresi, William N. Eskridge, Jr., Katrina L. Fischer, Eric Friedman, David Halberstam, Arthur D. Hellman, A.E. Dick Howard, Christian Iwasko, Vasan Kesavan, Ronald J. Krotoszynski, Jr., Nickolai Levin, Jeffrey Manns, Caleb Nelson, Richard A. Primus, Kate Stith, Laurence H. Tribe, and Mark Tushnet. Because a core part of the discussion in this Article centers on rapidly changing events and facts, it should be noted that editing on this Article was finished in October of 2002.

${ }^{1} 320$ U.S. 118 (1943).

${ }^{2}$ Id. at 136. See infra Part II.

${ }^{3} I d$. at 123 . 
sity of California at Los Angeles created forty-nine seminars with themes related to the attacks. Universities from Denver to New York City to Georgia have also added a large number of courses in response to the events of September 11. ${ }^{4}$ Law schools have not embraced post-September 11 curricular changes as quickly as universities in general have, ${ }^{5}$ and the legal academy has been slower to discuss the effects of September 11 on the mission of law schools. ${ }^{6}$ Now is the time, though, to discuss what impact September 11-and the issues leading up to September 11-should have on American legal education. As I have argued elsewhere, ${ }^{7}$ social

${ }^{4}$ Karen W. Arenson, Campuses Across America Are Adding 'Sept. 11 101' to Curriculums, N.Y. TIMES, Feb. 12, 2002, at A11.

${ }^{5}$ There are a couple of exceptions. Yale Law School, for example, offered a course in the spring of 2002 (taught by former Senator Gary Hart) called "Security and Public Policy in the $21^{\text {st }}$ Century American Republic," dealing extensively with the events of September 11. Yale Law School, Course Offerings (2002 Spring Term), available at http://www.law.yale.edu/outside/html/academics/acadspring.htm. Harvard Law School offered a course called "Terrorism in the 21st Century," taught by Professor Philip Heymann. Harvard Law School, Course Catalog (2001-2002), available at http://www.law.harvard.edu/students/catalog/catalog.php?op=show\&id=430.

${ }^{6}$ Many articles have been written that discuss the effects of September 11 on legal doctrine, but less attention has been given to the role of law schools and law classes in general. E.g., John W. Head, The United States and International Law After September 11, 11 KAN. J.L. \& PUB. POL'Y 1 (2001) (discussing what the United States legally could and should do in response to the September 11th terrorist attacks); Neal K. Katyal \& Laurence H. Tribe, Waging War, Deciding Guilt: Trying the Military Tribunals, 111 YALE L.J. 1259 (2002) (examining the constitutionality of military tribunals); George Ruthergen, Structural Uncertainty Over Habeus Corpus \& The Jurisdiction of Military Tribunals, 5 GREEN BAG 2d 397 (2002) (examining the debate regarding access to the writ of habeas corpus by suspected terrorists brought before military tribunals in terms of the lessons of the cases from the Civil War and World War II). The Harvard Journal of Law \& Public Policy published several articles from a symposium entitled Law and the War on Terrorism, 25 HARV. J. L. \& PUB. POL'Y 399 (2002). Some articles written before September 11 have made sure to mention the events of that day, even if they do not seem directly related to the topic of the article. E.g., Jack M. Balkin \& Sanford Levinson, Legal Historicism and Legal Academics: The Roles of Law Professors in the Wake of Bush v. Gore, 90 GEO. L.J. 173, 175 n.5 (2001) ("This Essay was written for a conference in Mark [Tushnet]'s honor in March 2001, long before the events of September 11, 2001. Since then, the times have become even more troubled and complicated, to put it mildly."); Richard A. Posner, Pragmatism Versus Purposivism in First Amendment Analysis, 54 STAN. L. REV. 737, 741 n.13 (2002) (noting that a comment made in the article about the role of freedom of speech in the time of war was "written before the September 11, 2001, terrorist attack on the United States"); Mark S. Nadel, Customized News Services and Extremist Enclaves in Republic.com, 54 STAN. L. REV. 831, 839 (2002) (reviewing CASS SunSTEIN, REPUBLIC.COM (2001)) (mentioning the "national traged[y]" that occurred on September 11, 2001). In a Harvard Law Review piece on the 2000 election, Laurence Tribe addressed the terrorist attacks as follows:

The terror that befell America on September 11, 2001 has led not only to great sadness but also to the reevaluation of much that might initially seem quite distant from the ruins of the World Trade Center. Even though this Comment was essentially completed by the time of the attack, I might have had second thoughts about the wisdom of publishing it now if its point were to question the legitimacy of the Bush presidency.

Laurence H. Tribe, EROG v. HSUB and Its Disguises: Freeing Bush v. Gore from its Hall of Mirrors, 115 HARV. L. REV. 170, 172 (2001).

${ }^{7}$ I have elsewhere discussed this notion that changes in law and society should impact the content of American legal education. First, I have argued that social changes such as multiculturalism should 
and political change should impact the content of law and, in this case, legal education.

This Article attempts to start the debate by focusing on the impact September 11 should have on the teaching of constitutional law classes, specifically by focusing on an interesting case that has remained largely undiscovered by American scholars and teachers. ${ }^{8}$ Schneiderman v. United States ${ }^{9}$ should be a part of the constitutional law canon, ${ }^{10}$ as it is a good case to teach in any point in history. The case for including Schneiderman in the constitutional law canon is even more compelling, however, in the aftermath of September 11, as the events of that day make the content and issues of Schneiderman particularly relevant. Sanford Levinson extensively discussed Schneiderman in his book Constitutional Faith, ${ }^{11}$ but the

make American constitutional law become more comparative and transnational. David Fontana, Refined Comparativism in Constitutional Law, 49 UCLA L. REv. 539 (2001). In a more descriptive mode, A.E. Dick Howard and I have looked at the role that social and political changes played in impacting the nature of American constitutional advising. David Fontana \& A.E. Dick Howard, The Changing Role of the American Constitutional Consultant (forthcoming) (discussing the role that changes in American society, foreign policy, and so on had on the role of American constitutional advisors overseas) (on file with the Connecticut Law Review).

${ }^{8}$ In digging up an otherwise unrecognized case and trying to demonstrate why it is important, I have looked extensively at other examples of pieces that have used exactly this technique. In a recent, provocative piece, Gary Lawson and Guy Seidman examined and extensively discussed the old case of Owings v. Speed, 18 U.S. (5 Wheat.) 420 (1820), in which the Court considered the application of the Contracts Clause (U.S. CONST. art. I, § 10, cl. 1.) to a Virginia law passed before the Constitution was ratified. Gary Lawson \& Guy Seidman, When Did the Constitution Become Law?, 77 Notre Dame L. Rev. 1, 1-3, 33-35 (2001). See also Vasan Kesavan, When Did the Articles of Confederation Cease to Be Law?, Notre DAme L. ReV (forthcoming 2002) (responding to the Lawson and Seidman article) (on file with the Connecticut Law Review). Before the Lawson and Seidman article, only seven articles available on Westlaw cited to that case: Bruce Ackerman \& Neal Katyal, Our Unconventional Founding, 62 U. CHI. L. Rev. 475, 558 n.246 (1995); Hans W. Baade, "Original Intent" in Historical Perspective: Some Critical Glosses, 69 TEX. L. REv. 1001, 1003 n.5 (1991); Hans W. Baade, Time and Meaning: Notes on the Intertemporal Law of Statutory Construction and Constitutional Interpretation, 43 Aм. J. Comp. L. 319, 337 n.144 (1995); David P. Currie, The Constitution in the Supreme Court: State and Congressional Powers, 1801-1835, 49 U. CHI. L. REV. 887, 921 n.237 (1982); James W. Ely, Jr., The Marshall Court and Property Rights: A Reappraisal, 33 J. MARShall L. REV. 1023, 1045 (2000); Mark R. Killenbeck \& Steve Sheppard, Another Such Victory? Term Limits, Section 2 of the Fourteenth Amendment, and the Right to Representation, 45 HASTINGS L.J. 1121, 1149 n.133 (1994); Ted L. Wills, Note, Religious Landmarks, Guidelines for Analysis: Free Exercise, Takings, and Least Restrictive Means, 53 OHIO ST. L.J. 211, 215 n.35 (1992). Richard Pildes has also written a piece digging up a generally underappreciated case. Richard H. Pildes, Democracy, Anti-Democracy, and the Canon, 17 Const. Comment. 295 (2000) (discussing Giles v. Harris, 189 U.S. 475 (1903), a case about disenfranchisement).

${ }^{9} 320$ U.S. 118 (1943).

${ }^{10}$ I use the term "canon" throughout this Article in the way the term traditionally has been used in discussions of the legal "canon." A canon is the collection of the most important or illuminating items in a particular field. See Black's Law DiCTIONARY 198 (7th ed. 1999). A canon is the collection of important cases. Cases that are part of the canon are termed "canonical." Id. In arguing that Schneiderman should be a part of the canon and should be a part of constitutional law class instruction, I leave the decision as to what cases or materials would or should be excluded for another day.

${ }^{11}$ SANFORD LEVINSON, CONSTITUTIONAL FAITH 122-54 (1988). 
case has otherwise received very little attention. ${ }^{12}$ Schneiderman, however, should be a part of all constitutional law classes in the aftermath of September 11. My framework for evaluating Schneiderman's status as a compelling case comes from the great deal of discussion in the last several years focusing on the existence of legal - and more specifically, constitutional-canons, whether such canons include specific opinions, statutes, or other materials. ${ }^{13}$ In discussing Schneiderman's importance, I will use this

${ }^{12}$ A search of major constitutional law and federal courts casebooks reveals no significant discussions of Schneiderman. See, e.g., Jerome A. BARRON ET AL., CONSTITUTIONAL LAW: PrinciPleS AND Policy (4th ed. 1996); William Cohen \& Jonathan D. Varat, Constitutional LaW (4th ed. 2000); DANIEl FARBER ET AL., CASES AND MATERIALS ON CONSTITUTIONAL LAW: THEMES FOR THE Constitution's Third Centruy (2d ed. 1998); Gerald Gunther \& KathleEn M. Sullivan, CONSTitutional LaW (13th ed. 1997); Ronald D. Rotunda, MODERn CONSTitutional LAW (6th ed. 2000); Geoffrey R. Stone et AL., Constitutional LaW (4th ed. 1996). But see David M. O'BRIEN, Constitutional LAW \& Politics 90, n.2 (4th ed. 2000) (briefly mentioning Schneiderman in a discussion of unconstitutional constitutional amendments). For the sake of full disclosure, I should mention that Professor O'Brien added this section after he and I had a very informative and interesting conservation about the issues presented by the case. Louis Fisher's casebook also briefly mentions the case in the context of discussing the high burden of proof for denaturalization established by Schneiderman. LOUIS FISHER, AMERICAN CONSTITUTIONAL LAW 327 (4th ed. 2001).

No law review article makes the major focus of its discussion the Schneiderman case, although the case is mentioned in law review articles on 146 occasions, according to a September 27, 2002 Westlaw search. Articles that mention Schneiderman almost always mention it in passing in the context of discussing the high burden of proof that the government must meet in order to denaturalize an American citizen (a standard that Schneiderman established). E.g., Ilene Durst, Lost in Translation: Why Due Process Demands Deference to the Refugee's Narrative, 53 RUTGERS L. REV. 127, 146 n.152 (2000) (citing Schneiderman for the rule that "[d]enaturalization . . . also must be proven by clear and convincing evidence") (citations omitted); Gerald L. Neuman, Federal Courts Issues in Immigration Law, 78 TEX. L. REV 1661, 1698-99 (2000) (citing Schneiderman for the proposition that "[1]ongstanding judicial interpretation protects the 'precious' right of citizenship by requiring the government to prove its case by the 'exacting standard' of 'clear, unequivocal and convincing evidence"') (citations omitted).

As discussed throughout this Article, Schneiderman has had enormous practical importance, which is reflected in the great deal of attention that Schneiderman has received in case law. Hundreds of cases have cited to Schneiderman, usually in the context of discussing the high burden of proof that must be met in denaturalization proceedings or other instances where the government is trying to deprive a person of a fundamental liberty. E.g., Cooper v. Oklahoma, 517 U.S. 348, 363 (1996) ("[W]e have held that due process places a heightened burden of proof on the State in civil proceedings in which the "individual interests at stake ... are both 'particularly important' and 'more substantial than mere loss of money."') (citing to Schneiderman for the burden of proof it established) (citations omitted); Cruzan v. Director, 497 U.S. 261, 282 (1990) ("This Court has mandated an intermediate standard of proof-'clear and convincing evidence'-when the individual interests at stake in a state proceeding are both 'particularly important' and 'more substantial than mere loss of money.' Thus, such a standard has been required in .. . denaturalization proceedings.") (citing to Schneiderman) (citations omitted).

${ }^{13}$ For a sampling of pieces of scholarship discussing the legal and/or constitutional canon, see, for example Legal Canons (J.M. Balkin \& Sanford Levison eds., 2000); Frances Lee Ansley, Race and the Core Curriculum in Legal Education, 79 CAL. L. REV. 1511 (1991); J.M. Balkin \& Sanford Levinson, The Canons of Constitutional Law, 111 HARV. L. REv. 963 (1998); David E. Marion, The State of the Canon in Constitutional Law: Lessons from the Jurisprudence of John Marshall, 9 WM. \& MARY Bill RTS. J. 385 (2001); Francis J. Mootz III, Legal Classics: After Deconstructing the Legal Canon, 72 N.C. L. Rev. 977 (1994); Richard A. Primus, Canon, Anti-Canon, and Judicial Dissent, 48 DuKE L.J. 243 (1998); Judith Resnik, Constructing the Canon, 2 YALE J.L. \& Human. 221 (1990); Judith 
framework and attempt to add several new wrinkles to this framework in my discussions of the canon.

In the leading article on this topic, Jack M. Balkin and Sanford Levinson examined the nature of the constitutional canon and the materials that should be part of the canon. ${ }^{14}$ Balkin and Levinson discuss "three different ways that the question of the canon might be articulated in the field of constitutional law." 15 First, a canon might be defined by asking what "key cases and materials should be taught in constitutional law courses and reprinted in constitutional law casebooks" ${ }^{\prime 16}$ in order to help law teachers train law students to become the best lawyers they can be. Balkin and Levinson call this the "pedagogical canon." 17

The pedagogical canon can take one of two forms. First of all, an item can be considered a member of the pedagogical canon because it prepares students for addressing doctrinal issues they will face in their legal careers. I will call this the "doctrinal pedagogical canon." 18 Second of all, although the item may not be of much practical legal doctrinal importance, it illustrates general styles of legal reasoning, judicial strategy, and general issues that lawyers face. I will call this the "illustrative pedagogical canon." 19

Second, a canon might be defined by asking "what key cases and materials any educated person should be aware of in order to participate in serious discussions about American constitutional development." ${ }^{20}$ Balkin and

Resnik, Revising the Canon: Feminist Help in Teaching Procedure, 61 U. CIN. L. REV. 1181 (1993). See also Symposium, The Canon(s) of Constitutional Law, 17 Const. Comment. 187 (2000) (discussing the teaching of constitutional canons in non-judicial settings). This scholarship has tended to build on the scholarship in other areas - mostly in literature - that discusses the content of the canon in those particular areas. E.g., HAROLD BloOM, THE WESTERN CANON: THE BOOKS AND SCHOOLS OF THE AGES (1994) (studying authors considered to be part of the literary canon); HENRY LOUIS GATES, JR., LOOSE CANONS: NOTES ON THE CUlTURE WARS 22-42 (1992) (discussing the effect of the debate over canon formation on the development of African-American literature as a subject of instruction in the American academy); LAWRENCE W. LeVINE, THE OPENING OF THE AMERICAN Mind: CANONS, CUlTURE, AND HISTORY 91-101 (1996) (discussing the emergence of American literature and American studies in the canon and the curriculum).

${ }^{14}$ Balkin \& Levinson, supra note 13.

${ }^{15} \mathrm{Id}$. at 975 .

${ }^{16} I d$.

${ }^{17} I d$.

${ }^{18}$ As Balkin and Levinson point out, with the exception of a handful of lawyers (almost all of whom are based in Washington D.C.), most lawyers will never face a case that involves a constitutional law issue in their entire life (and indeed most lawyers do not work in litigation and thus will never face a "case" in the first place). Id. at 977 ("Indeed, if preparation for the practical realities of legal practice is the central aim of pedagogy, then why should law students spend so much time on constitutional issues at all, given that most students will rarely be confronted with such issues?"). See also KEVIN T. McGuire, The Supreme Court Bar: Legal Elites in the Washington Community (1993) (discussing the limited number of Washington lawyers who are members of the Supreme Court Bar).

${ }^{19}$ See Balkin \& Levinson, supra note 13, at 977.

${ }^{20} \mathrm{Id}$. at $975-76$ 
Levinson call this the "cultural literacy canon." ${ }^{21}$ Finally, Balkin and Levinson discuss what they call the "academic theory canon" 22 or the "theoretical canon." ${ }^{.23}$ According to this understanding of the canon, a particular item becomes canonical because "it concerns the materials that a young assistant professor ought to study if he or she wants recognition as an active participant in the field." 24 Under each understanding of the canon, materials beyond Supreme Court cases should be included as part of the canon. $^{25}$

In arguing that Schneiderman should be part of the constitutional canon, this Article will add to and refine Balkin's and Levinson's conception of the canon. Balkin and Levinson generally fail to consider that the canon must include a contextualist or historicist element. In other words, the canon will not necessarily include the same materials throughout different periods of time. As society and law change, ${ }^{26}$ so should the canon.

${ }^{21} I d$. at 976. Balkin and Levinson consider Dred Scott v. Sandford, 60 U.S. (19 How.) 393 (1856), to be an example of a case that is part of the cultural literacy canon. Id.

${ }^{22}$ Id.

${ }^{23}$ Balkin and Levinson introduce this phrase on page 976 of their article, although they at first refer to this notion of the canon as the "academic theory canon." Id. I will use the phrase "theoretical canon" throughout this Article.

${ }^{24} \mathrm{Id}$. at $978-79$.

${ }^{25}$ Balkin and Levinson argue that in addition to determining the content of the materials that should be included in the constitutional canon, other commentators should make sure to consider the form of these materials, and have heretofore focused almost exclusively on cases. Id. at 970 ("[W]e contend that the pedagogical canon in constitutional law is much too centered on the opinions of the Supreme Court of the United States.”).

Presumably, Balkin and Levinson would therefore be interested in various sorts of non-legal materials beyond the Frederick Douglass speech they discuss in their article. Id. at 964-67 (discussing Fredrick Douglass's Glasgow Address). For instance, they might be interested in discussions of the political and personal backgrounds of judges, of the inner battles within courts, and of the political and foreign policy elements of cases, because all of these subjects may be valuable non-legal elements that can add some insights to discussions of constitutional law. Using the framework of each of the three Balkin-Levinson categories helps illuminate why such interdisciplinary work/aspects of law can be valuable additions to the canon. Such non-legal notions or aspects of cases are surely present in the real world of practice. Knowledge of the political situation surrounding a case, and the personalities of the judges hearing a case, for example, are all important elements of legal analysis - and thus are dilemmas faced by lawyers in the real world. Indeed, the non-legal aspects of constitutional law cases might be more relevant to practicing lawyers than the traditional, constitutional doctrinal aspects of constitutional law cases. As a practical matter, a lawyer is more likely to face a case with a judge who has a clear, specific political background or agenda (a non-legal consideration), whether the judge be an administrative law judge, a federal district court judge, etc., than a lawyer is to face a case that has an equal protection component. This is because very few law students will become part of the Supreme Court bar or ever argue a case with a constitutional component. Balkin \& Levinson, supra note 18.

${ }^{26}$ Contextualization of the canon can take one of two forms. First, contextualism can be external to law: Society can change and can apply new forces on constitutional law. For instance, increasing religious and cultural diversity has led to a number of interesting issues and cases. E.g., Employment Division v. Smith, 494 U.S. 872 (1990) (dealing with First Amendment rights in connection with the use of peyote for religious purposes); Wisconsin v. Yoder, 406 U.S. 205 (1972) (addressing the First Amendment rights of the Amish to refuse to send their children to compulsory state schools); Sherbert v. Verner, 374 U.S. 398 (1963) (litigating the claim of a Seventh-Day Adventist who was denied un- 
Different materials will be relevant to legal practice (pedagogical canon), to being a good citizen (cultural literacy canon) or to being a good academic (theoretical canon) as times and law change. This is what I am arguing should result from the events of September 11-social change should make the composition of the constitutional canon change as well.

Balkin and Levinson generally do not discuss the fact that more interesting and provocative cases, or other materials, can better illustrate a legal issue. I refer to this as the "interest element" of the canon. Certain cases or other materials might be included in the canon because, although they are just as substantively valuable as other materials, the interesting nature of the material might make it more valuable as a teaching tool (pedagogical canon), a tool for teaching citizens about their world (cultural literacy canon), or as a tool for keeping scholars informed about their craft (theoretical canon).

Finally, Balkin and Levinson briefly allude to, and this Article attempts to expand upon, the role that non-judicial materials might play in the canon. ${ }^{27}$ In particular, this Article discusses various ways in which constitutional law casebooks and classes neglect to consider the insights of political science studies of courts. This Article discusses the ways in which students might learn more about the real workings of the law by applying political science insights to Schneiderman.

This Article addresses the consequences of September 11 by applying the Balkin-Levinson framework to Schneiderman v. United States. ${ }^{28}$ Part II of this Article describes Schneiderman v. United States, a 1943 case nominally about denaturalization, that came to be about the core meanings of American national identity, American judicial behavior during wartime, and American immigration policy. ${ }^{29}$ Part II traces the case from its origins in the district court all the way up to the United States Supreme Court and gives a brief overview of the case. The many interesting legal and nonlegal elements of the case will be discussed in greater detail in Part III, which analyzes the reasons why Schneiderman is a particularly good member of the constitutional canon. Part III applies the Balkin-Levinson

employment benefits after being fired for refusing to work on the Sabbath). See generally Fontana, supra note 7 (arguing that social changes should make American constitutional law more comparative and transnational). In this sense (to tweak a phrase from Robert Cover, although I am using it in a different manner), social change can be canonical-generative, creating new members of the constitutional canon. Robert M. Cover, The Supreme Court, 1982 Term-Foreword: Nomos and Narrative, 97 HARV. L. REv. 4, 15 (1983) (introducing the phrase "jurisgenerative," meaning the creation of new jurisprudential meanings). Second, contextualization can be internal: The law itself can change, leading to new materials that should be included in the canon. For a further discussion of these two dynamics in the context of constitutional change overseas, see Fontana \& Howard, supra note 7.

${ }^{27}$ Balkin \& Levinson, supra note 13 , at 1016.

${ }^{28} 320$ U.S. 118 (1943).

${ }^{29}$ Id. 
framework and concludes that Schneiderman v. United States should be a part of the constitutional canon in the twenty-first century because it illustrates many of the core battles and debates that will dominate constitutional law over the next several years and, more than likely, over the next century. The case has all of the legal and non-legal elements that makes a case exceptional, worth teaching even before September 11. Schneiderman also has a number of additional elements that are particularly appropriate subjects of discussion in the post-September 11 constitutional law classroom. Finally, Part IV provides a brief conclusion.

\section{SCHNEIDERMAN V. UNITED STATES}

William Schneiderman became a citizen of the United States in $1927 .{ }^{30}$ Schneiderman was naturalized in 1927, although he was an active member of the Workers (Communist) Party of America and the Young Workers (Communist) League of America. ${ }^{31}$ The statute governing naturalizations at the time stated:

It shall be made to appear to the satisfaction of the court admitting any alien to citizenship that immediately preceding the date of his application he has resided continuously within the United States five years at least, and within the State or Territory where such court is at the time held one year at least, and that during that time he has behaved as a man of good moral character, attached to the principles of the Constitution of the United States, and well disposed to the good order and happiness of the same. In addition to the oath of the applicant, the testimony of at least two witnesses, citizens of the United States, as to the facts of residence, moral character, and attachment to the principles of the Constitution shall be required, and the name, place of residence, and occupation of each witness shall be set forth in the record. ${ }^{32}$

Thus, in order to be naturalized as a citizen, Schneiderman had to claim to be a person "attach[ed] to the principles of the Constitution" of the United States. Schneiderman did precisely that, and he became a naturalized citizen of the United States.

In the late 1930s and early 1940s, with the war in Europe just beginning, political pressure obviously encouraged governmental leaders to persecute and even prosecute allegedly disloyal citizens. At the same time, American attention began to focus more on the danger posed by the Com-

\footnotetext{
${ }^{30} I d$. at 126.

${ }^{31} \mathrm{Id}$. at 126-27.

${ }^{32}$ Act of June 29, 1906, ch. 3592, § 4, 34 Stat. 596, 598 [hereinafter Naturalization Act] (emphasis added).
} 
munist Soviet Union. Therefore, in 1939, the United States attempted to revoke Schneiderman's citizenship most likely to strike a blow against possible disloyalty, especially pro-Communist or pro-Nazi behavior at a time when the Soviet Union was fighting against American interests in World War II.

The United States relied on Section 15 of the 1906 statute, which authorized the United States Attorney General to institute a suit to set aside a certificate of naturalization "on the ground of fraud or on the ground that such certificate of citizenship was illegally procured." ${ }^{33}$ The United States relied upon the second of these grounds (illegally procured citizenship) in its denaturalization lawsuit because it asserted that Schneiderman's communist activity meant that he could not be "attached to the principles of the Constitution of the United States." 34 The federal district court in California ruled in favor of the government and revoked Schneiderman's citizenship, finding that Schneiderman had pursued "unconstitutional objectives by unconstitutional means." 35 The Ninth Circuit Court of Appeals affirmed the lower court's decision, stating that:

There was substantial evidence which, if believed, leads to the conclusion that the Communist Party held and advocated that private ownership of the agents of production was wrong; that the agents of production should be confiscated by the government without compensation to the private owners thereof; that the government should be a dictatorship of the proletariat; that the present government here should be abandoned and one like that of the Soviet Union established; that the Supreme Court and the Senate should be abolished; that the government should be controlled by one political party only, and all others should be suppressed; and that the various countries of the world should establish a world union of Soviet Socialist Republics. It is obvious that these views are not those of our Constitution. ${ }^{36}$

Schneiderman appealed to the United States Supreme Court. The case attracted a lot of attention and a number of prominent lawyers, even for a Supreme Court case. Solicitor General Charles Fahy argued for the government, focusing on the meaning of the statutory language "attach[ed] to the principles of the Constitution" 37 of the United States. Fahy argued that

\footnotetext{
${ }^{33} I d . \S 15$.

${ }^{34}$ United States v. Schneiderman, 33 F. Supp. 510,511 (N.D. Cal. 1940).

${ }^{35} \mathrm{Id}$. at 512-13. According to the district court, the unconstitutional objectives that Schneiderman pursued included some of the basic tenets of Communism (abolishing private property, etc.), which the district court held were so fundamentally at odds with the United States Constitution that they were unconstitutional. Id. Moreover, the district court found that Schneiderman advocated "methods of force and violence" to achieve these ends. Id. (citation omitted).

${ }^{36}$ Schneiderman v. United States, 119 F.2d 500, 503-04 (9th Cir. 1941) (emphasis added).

${ }^{37}$ See generally Brief for the United States, Schneiderman v. United States, 320 U.S. 118 (1943) (No. 2) [hereinafter Brief]. For a look at how one justice viewed the Schneiderman case, see JOSEPH LASH, FROM THE DIARIES OF FELIX FRANKFURTER 208-17, 248-50, 257-59, 310-11 (1975).
} 
holding a belief "that the laws and the Constitution should be amended in some or many respects" ${ }^{\prime 3}$ was not enough to prove non-attachment to the Constitution. An alien must, according to Fahy, "belie[ve] in and sincere[ly] adhere[] to" the Constitution's "general political philosophy." 39 Fahy presented a test to see if an alien was attached to the general political philosophy of the Constitution:

The test is ... whether [an alien] substitutes revolution for evolution, destruction for construction, whether he believes in an ordered society, a government of laws, under which the powers of government are granted by the people but under a grant which itself preserves to the individual and to minorities certain rights or freedoms which even the majority may not take away; whether, in sum, the events which began at least no further back than the Declaration of Independence, followed by the Revolutionary War and the adoption of the Constitution, establish principles with respect to government, the individual, the minority and the majority, by which ordered liberty is replaced by disorganized liberty. ${ }^{40}$

Thus, according to Fahy, there is a hierarchy of principles within the Constitution, with some principles more fundamental than others. To believe in the Constitution means believing in these fundamental principles, and to believe in the Constitution means that you cannot believe in changing these principles. $^{41}$

${ }^{38}$ Brief, supra note 37 , at 104 .

${ }^{39} \mathrm{Id}$. at 103 .

${ }^{40} I d$. at 105 .

${ }^{41}$ There is obviously a leap from saying that one must believe in certain core provisions to saying that one must believe these certain core provisions should be unamendable. An argument could be made that one could believe deeply in certain core provisions of the Constitution even while wanting to change them significantly, although this is debatable and the eventual opinions issued by the Court in Schneiderman do not seem to agree with this argument. The majority seems to believe that Article V is the core provision of the Constitution, and therefore one must believe in that, and not want to change that, in order to believe in the Constitution. The dissenters have a broader definition of core provisions of the Constitution, and thus there are various discrete issues at play here: (1) Are some provisions of the Constitution more important than others? (2) If so, what are those provisions? (3) How easy or hard should it be to change those provisions? (4) Does believing in one of these provisions mean that changing such a provision should be impossible or more difficult or somehow problematic?

Many other questions come to mind that were generally ignored by the Schneiderman opinion: For instance, the Court uses potential limitations to constitutional amendments as a means of measuring one's attachment to that document. This is a questionable proposition. Does not believing in equal suffrage (one of the special provisions that is harder to change in the Constitution) mean that one does not believe in the core of the Constitution? As demonstrated by this brief posing of the question, it is not at all clear that the most important provisions of the Constitution are the ones that are/should be generally the hardest ones to change.

Solicitor General Fahy presents various versions of the argument as applied to the notion of "core" and less important constitutional provisions, versions that I develop elsewhere. David Fontana, Substantive Limitations on Constitutional Change in Germany, India and the United States (manuscript on file with the Connecticut Law Review). Fahy presents a version that I elsewhere call the "absolute 
Arguing for Schneiderman, the recently defeated 1940 Republican presidential candidate Wendell Willkie asserted that the absence of substantive limitations on changes in Article $\mathrm{V}$, beyond the slavery and equal representation provisos, ${ }^{42}$ meant that "a person can be attached to the Constitution no matter how extensive the changes are that he desires, so long as he seeks to achieve his ends within the framework of Article V." 43 Note that, according to Willkie, the Constitution was an absolute entrenchment document, but only in a limited sense, and now is solely a hierarchical en-

entrenchment" version of the Constitution. This version of the Constitution essentially holds that certain constitutional provisions cannot be changed, no matter what process is used to change these provisions (supermajority vote, constitutional convention, etc.) if the Constitution is to remain the same Constitution. Id. For the comparative constitutionalist, Fahy's argument sounds like the concept that has come to be at the core of German constitutional law-the concept of a "hierarchy of values" and unconstitutionality of certain constitutional amendments. Article 79, paragraph 3 of the German Basic Law prevents amending the Basic Law, no matter what procedure is used, to affect the German system of federalism or principles of human dignity. GRUNDGESETZ [GG] [Constitution] art. 79(3) (F.R.G.) (translated in AmOS J. PEASLEE, Basic Law of the Federal Republic of Germany, in 3 Constitutions OF NATIONS (Dorothy Peaslee Xydis ed. 3d ed. 1968)) (“An amendment of this Basic Law affecting the division of the Federation into Laender, the participation in principle of the Laender in legislation, or the basic principles laid down in Articles 1 and 20, shall be inadmissible."). The German Constitutional Court enforced this clause because it believed that some "principles . . . are so fundamental and to such an extent an expression of a law that [they] precede[] even the constitution that they also bind the framer of the constitution ...." Walter F. MURPHY \& JosePh TANENHAUS, COMPARATIVE CONSTITUTIONAL LAW 208-12 (1977) (citing the Bavarian Constitutional Court, from Southwest Case BverfGE 1, 14 (1951)).

Fahy also presents a version that I call the "hierarchical entrenchment" version of the Constitution, which holds that certain constitutional provisions can only be changed through a more rigorous procedural mechanism similar that is required to change other constitutional provisions. For the comparative constitutionalist, this notion will obviously sound like the "basic structure" strain of doctrine in Indian constitutional law. The Indian Supreme Court has created a several-tiered hierarchy that makes it more difficult to pass amendments that violate the "basic structure" or "essential features" of the Indian Constitution. E.g., Kesavananda v. Kerala, [1973] S.C.R. 1461 (India). The third version of the Constitution discussed by Fahy is the "temporary proceduralism" Constitution, which holds that all constitutional provisions can be changed through the same process.

${ }^{42}$ Article V of the United States Constitution states :

The Congress, whenever two thirds of both Houses shall deem it necessary, shall propose Amendments to this Constitution, or on the Application of the Legislatures of two thirds of the several States, shall call a Convention for proposing Amendments, which, in either Case, shall be valid to all Intents and Purposes, as Part of this Constitution, when ratified by the Legislatures of three fourths of the several States, or by Conventions in three fourths thereof, as the one or the other Mode of Ratification may be proposed by the Congress; Provided that no Amendment which may be made prior to the Year One thousand eight hundred and eight shall in any Manner affect the first and fourth Clauses in the Ninth Section of the first Article; and that no State, without its Consent, shall be deprived of its equal Suffrage in the Senate. U.S. CONST. art. V.

These two limitations do not function in the same manner. The slavery proviso functions like what I called the "absolute entrenchment constitutional provision" notion put forth by Fahy. See generally Brief, supra notes 37-40 and accompanying text. See also MURPhy \& TANENHAUS, supra note 41 and accompanying text. In other words, for the Constitution to be this Constitution, there could be no amendments addressing slavery before 1808 . The equal representation proviso, however, functions like what I elsewhere called the "hierarchical entrenchment constitution provision."

${ }^{43}$ United States v. Schneiderman, 320 U.S. 118, 140 (1943). 
trenchment document. Before 1808, no matter the procedure used, no change could be made to the Constitution that "in any manner affect[ed] the first and fourth Clauses in the Ninth Section of the first Article" 44 of the Constitution. This is, of course, an absolute entrenchment provision. There was also a hierarchical entrenchment provision: States could be "deprived of [] equal suffrage in the Senate," but only via a special process (a process requiring the consent of the State being deprived of equal suffrage). ${ }^{45}$

After 1808, with the absolute entrenchment provision having expired, only the hierarchical entrenchment provision lasted. Thus, according to Willkie, the only limitation on constitutional amendments was this hierarchical entrenchment limitation relating to equal suffrage in the Senate. All other constitutional changes were permissible and need only abide by the strictures of Article V. Thus, the Constitution was basically a temporary proceduralism document, with one exception.

The Court agreed with Willkie, although it stopped short of adopting an obviously temporary proceduralist interpretation of the Constitution. Justice Frank Murphy wrote the opinion of the Court, ${ }^{46}$ emphasizing a constitutional procedural point: For constitutional reasons, the government cannot set aside an award of citizenship "years after it was granted.",47

Because of the grave loss suffered by a denaturalized citizen and the constitutional status of that loss, the Constitution requires that his citizenship could only be taken away with "the clearest sort of justification and proof." 48 Justice Murphy discussed what it means to be "attached to the principles of the Constitution of the United States," using the First Amendment to dictate his interpretation of that phase. ${ }^{49}$ Justice Murphy looked at Communist documents that called for the abolition of private property without compensation, the establishment of a proletarian dictatorship with political rights denied to persons who were not proletarian and/or members of the Party, and the creation of an international union of Soviet Republics, and concluded that believing in these doctrines did not necessarily mean that one was not attached to the principles of the Constitution. ${ }^{50}$ Justice Murphy wrote that " $[\mathrm{t}]$ he constitutional fathers, fresh from a

\footnotetext{
${ }^{44}$ U.S. CONST. art. V.

${ }^{45} \mathrm{Id}$.

${ }^{46}$ Justice Robert Jackson did not participate in the Court's deliberations or in the eventual 5-3 decision. Id. at 207. Justice Jackson stated:

This case was instituted in June of 1939 and tried in December of that year. In January 1940, I became Attorney General of the United States and succeeded to official responsibility for it. This I have considered a cause for disqualification, and I desire the reason to be a matter of record.

Id. (Jackson, J.) (citations omitted).

${ }^{47}$ Id. at $122-23$

${ }^{48} \mathrm{Id}$. at 122.

${ }^{49} I d$. at $137-45$.

${ }^{50}$ Id. at $136-39$.
} 
revolution, did not forge a political strait-jacket for the generations to come." 51 Justice Murphy emphasized the presence of Article V, coupled with the "many important and far-reaching changes made in the Constitution since 1787,", 52 and argued that these changes "refute the idea that attachment to any particular provision or provisions is essential, or that one who advocates radical changes is necessarily not attached to the Constitution." 53

Justice William O. Douglas wrote a concurring opinion, arguing that the 1906 statute should be interpreted to mean that only fraud could be a basis for revoking naturalization. ${ }^{54}$ Justice Wiley Rutledge concurred, arguing that revoking Schneiderman's citizenship would result in a permanent twoclass system of citizenship, whereby naturalized American citizens had to perpetually fear that they were in danger of being deported. ${ }^{55}$ Chief Justice Harlan Fiske Stone wrote the dissenting opinion (joined by Justices Felix Frankfurter and Owen Roberts) adopting Fahy's arguments. ${ }^{56}$ Chief Justice Stone believed that there was a hierarchy of principles in the Constitution, and that attachment to the Constitution means that one had to believe in certain fundamental constitutional principles, which he defined as, "[t]he principle of constitutional protection of civil rights and of life, liberty and property, the principle of representative government, and the principle that constitutional laws are not to be broken down by planned disobedience." Chief Justice Stone continued:

I assume also that all the principles of the Constitution are hostile to dictatorship and minority rule; and that it is a principle of our Constitution that change in the organization of our government is to be effected by the orderly procedures ordained by the Constitution and not by force or fraud. ${ }^{58}$

Chief Justice Stone examined Communist party documents ranging from Stalin's Theory and Practice of Leninism ${ }^{59}$ to the ABCs of Communism. ${ }^{60}$ The Chief Justice concluded from these and other documents that

${ }^{51} I d$. at 137.

${ }^{52} \mathrm{Id}$.

${ }^{53} \mathrm{Id}$.

${ }^{54} I d$. at 161-65 (Douglas, J., concurring).

${ }^{55} \mathrm{Id}$. at 165-70 (Rutledge, J., concurring).

${ }^{56} I d$. at 170-97 (Stone, C.J., dissenting).

${ }^{57} I d$. at 181 (Stone, C.J., dissenting).

${ }^{58}$ Id. (Stone, C.J., dissenting).

${ }^{59} I d$. at 191 n. 12 (Stone, C.J., dissenting) (citation omitted).

${ }^{60} \mathrm{Id}$. at 190 n.11 (Stone, C.J., dissenting) (citing N. BUCHARIN \& E. PREBRASCHENSKY, ABCs OF COMMUNISM 69 (Lyceum-Literature Department, Workers Party of America trans., 1921)). Bucharin and Prebraschensky wrote this pamphlet prior to their expulsion from the Russian Communist Party. Id. 
the Party - and therefore Schneiderman - was committed to violent revolution and to overthrowing the fundamental principles of the United States Constitution. ${ }^{61}$ If Schneiderman had his way, according to Chief Justice Stone, then there would be an abandonment of "existing constitutional principles" ${ }^{2}$ and the basic core of the "freedoms guaranteed by the Bill of Rights [would] be ended." ${ }^{63}$ Therefore, Chief Justice Stone had no problem concluding that the record demonstrated "a basis for finding in the Party teachings, during the period in question, an unqualified hostility to the most fundamental and universally recognized principles of the Constitution."

The Schneiderman case is particularly fascinating for the range of discussions and rulings in the opinions of the Court. As partially compelled by the First Amendment and the general constitutional design, the majority interpreted the phrase "attached to the principles of the Constitution" to mean that the Constitution was a "limited absolute/hierarchical entrenchment" document. ${ }^{65}$ Also, as dictated by the Constitution's protection of fundamental liberties, the Court held that citizenship could not be stripped without the most clear and compelling evidence. ${ }^{66}$ The Court issued these rulings in 1943, a crucial year during World War II when domestic pressure to crack down on dissenters and critics of the American system was seemingly at its greatest.

\section{SCHNEIDERMAN V. UNITED STATES AS A MEMBER OF THE CONSTI- TUTIONAL CANON}

This Part evaluates Schneiderman's chances of being considered a part of the constitutional canon. Schneiderman has an unusually large number of the elements of a canonical case for one particular case. Indeed, after September 11, many of these elements, although always reason to make Schneiderman part of the canon, are even more compelling proof of Schneiderman's canonical status. While other cases may be good examples of one particular aspect of the constitutional canon, ${ }^{67}$ rarely will a case

${ }^{61}$ See id. at 188 n.6, 197-207 (Stone, C.J., dissenting) (citation omitted).

${ }^{62}$ Id. at 193 (Stone, C.J., dissenting).

${ }^{63} \mathrm{Id}$. at 193-94 (Stone, C.J. dissenting).

${ }^{64} I d$. at 195 (Stone, C.J., dissenting).

${ }^{65}$ See id. at $137-44$.

${ }^{66} \mathrm{Id}$. at 158.

${ }^{67}$ Brown v. Board of Education, 347 U.S. 483 (1954), is an excellent example of the cultural literacy canon because of its practical impact. However, whether or not it did have this practical impact is widely debated by those inside and outside the traditional legal academy. E.g., MALCOLM M. FeELEY \& Edward L. Rubin, Judicial Policy Making and the Modern State: How the Courts ReFORMED AMERICA'S PRISONS 38, 159, 160, 220-21, 255, 316 (1998) (discussing the effects of judicial activism on the prison system); Gerald N. Rosenberg, THE Hollow Hope: CAN COURTS BRING ABOUT SOCIAL CHANGE? 42-50 (1991) (discussing the role of the judiciary in civil rights, abortion and women's rights, the environment, and criminal law). 
have so many elements of what makes a case a member of the canon (or simply a good case to teach) as does Schneiderman. Nor will a case be so appropriate for a particular period of time. ${ }^{68}$ The case presents compelling issues and has an extensive background analysis of several important matters facing law students and lawyers (in their special citizenship role as trustees of the law for the general public). However, as I will discuss in Part III.A, there are also many reasons to include Schneiderman within the canon because of its status in the pedagogical canon.

\section{A. The Pedagogical Canon and Schneiderman}

The entire Schneiderman drama illustrates several of the elements of what makes a case a good candidate for the pedagogical canon. First, Schneiderman features several doctrinal elements and general legal debates that contemporary lawyers face in their legal practice, conceived of at a very broad level, and is thus a good case to include within the doctrinal pedagogical canon. ${ }^{69}$ Second, Schneiderman features several of the less doctrinal elements of cases that lawyers face, and thus is a particularly good case to situate in the illustrative pedagogical canon. ${ }^{70}$

Justice Murphy's opinion is an opinion that falls within the tradition of United States v. Carolene Products' footnote four, ${ }^{71}$ "the most celebrated footnote in constitutional law,"72 which triggered a debate about substance versus procedure in constitutional interpretation (and law in general). ${ }^{73}$ Chief Justice Harlan Fiske Stone (ironically the author of the Schneiderman opinion that prioritizes substance over procedure) wrote in Carolene Products that:

There may be [a] narrower scope for operation of the presumption of constitutionality when legislation appears on its face to be within a specific prohibition of the Constitution ... . It is unnecessary to consider now whether legislation which restricts those political processes which can ordinarily be expected to bring about repeal of undesirable legislation, is to

\footnotetext{
${ }^{68}$ This illustrates the contextualization idea, as discussed earlier, which is neglected in Balkan's and Levison's discussion. Supra note 26 and accompanying text.

${ }^{69}$ See Balkin \& Levinson, supra note 13, at 975.

${ }^{70}$ See id. at $975-77$.

${ }^{71}$ United States v. Carolene Prods., 304 U.S. 144, 152 n.4 (1938).

${ }^{72}$ Lewis F. Powell, Jr., Carolene Products Revisited, 82 ColuM. L. REv. 1087, 1087 (1982) (footnote omitted).

${ }^{73}$ Ronald Dworkin, Freedom's Law: The Moral Reading of the American ConstituTION 72-83 (1996); Laurence H. Tribe, The Puzzling Persistence of Process-Based Constitutional Theories, 89 YALE L.J. 1063 (1980); Peter Westen, The Empty Idea of Equality, 95 HARV. L. ReV. 537 (1982).
} 
be subjected to more exacting judicial scrutiny under the general prohibitions of the Fourteenth Amendment than are most other types of legislation .... Nor need we enquire whether similar considerations enter into the review of statutes directed at particular religious ... or national ... or racial minorities ... whether prejudice against discrete and insular minorities may be a special condition, which tends seriously to curtail the operation of those political processes ordinarily to be relied upon to protect minorities, and which may call for a correspondingly more searching judicial inquiry. ${ }^{74}$

In this footnote, Chief Justice Stone explicitly provided an approach through which the post-1937 Supreme Court could maintain its role in American democracy. He clearly presented three situations in which the Court would not assume the constitutionality of enacted legislation, as it had done with business regulations in NLRB v. Jones \& Laughlin Steel Corp. ${ }^{75}$ West Coast Hotel v. Parrish ${ }^{76}$ and South Carolina Highway Department v. Barnwell Brothers. ${ }^{77}$ The Court would, according to footnote four, subject legislation to a stricter standard than a simple rational basis test when such legislation seemed to impact the processes of political activity by, for example, impacting the political liberties of certain minority groups.

Like the discussion in footnote four, Justice Murphy's opinion in Schneiderman glorifies process over substance. ${ }^{78}$ Justice Murphy evaluates William Schneiderman's attachment to the procedural apparatus for changing the Constitution. This is why Justice Murphy evaluates Communist Party documents, because so long as Schneiderman believes in processorderly, legal procedures over the use of violence and anarchy-then Schneiderman is attached to the Constitution. ${ }^{79}$ Just as footnote four implicitly says that the fundamental core of the Constitution deals with protecting the integrity and fairness of political processes, Justice Murphy's Schneiderman opinion celebrates Schneiderman's attachment to the Constitution so long as he too respects the integrity (that is to say, the peacefulness) of the political process specified by the Constitution for its amendment. By contrast, Chief Justice Stone's opinion prioritizes substance over procedure; his opinion identifies certain substantive constitutional provisions as being extremely important, and asserts the correct interpretation of the United States Constitution is a substantive rather than a

\footnotetext{
${ }^{74}$ Carolene Prods., 304 U.S. at 152 n.4.

${ }^{75} 301$ U.S. 1 (1937).

${ }^{76} 300$ U.S. 379 (1937).

77303 U.S. 177 (1938)

${ }^{78}$ Schneiderman, 320 U.S. 118, 133-36 (1943).

${ }^{79}$ Id.
} 
procedural one.

This procedure versus substance debate has been at the center of many areas of American constitutional law ever since footnote four and is raised again by John Hart Ely's landmark book. ${ }^{80}$ It is also at the core of much of the debate in contemporary constitutional law scholarship. Thus, the battle of procedure versus substance in Schneiderman is of importance for the theoretical canon as well. Of course, hardly any constitutional doctrinal issues, if there are indeed any at all, are relevant to the everyday practice of law. ${ }^{81}$ Those constitutional issues that might be relevant to the practice of law, though, do feature debates about procedure versus substance. For instance, many lawyers must consider the issues presented by takings law. Courts are much less likely to uphold governmental actions affecting property interests if the taking benefits one narrow interest rather than the public at large, ${ }^{82}$ although some cases say that it is not the content of the takings action but rather the process that led up to the governmental taking that determines the outcome. ${ }^{83}$

Moreover, the procedure versus substance debate in Schneiderman arises regularly in other areas of law practice, not just in the area of constitutional litigation. It is at the heart of debate over federal Indian law, and especially at the heart of the debate over the theories of Felix Solomon Cohen, the chief legal architect of federal Indian policy, and an important legal philosopher in his own right. ${ }^{84}$ The debate over procedure versus substance is evident in the battles over the Indian Reorganization Act ("IRA"), ${ }^{85}$ which initiated the Indian New Deal by creating a procedure to re-establish tribal governments on Indian reservations, ${ }^{86}$ The Handbook of Federal Indian Law ${ }^{87}$ and the Indian Claims Commission Act ("ICCA"). ${ }^{88}$

${ }^{80}$ John HART Ely, DEMOCRACY AND Distrust: A THeORY OF Judicial REVIEW (1980).

${ }^{81}$ Balkin \& Levinson, supra note 13.

${ }^{82} \mathrm{~Pa}$. Coal Co. v. Mahon, 260 U.S. 393, 413 (1922).

${ }^{83}$ For a discussion of these cases and this argument, see ELY, supra note 80, at 80-88 (1980); Frank I. Michelman, Political Markets and Community Self-Determination: Competing Judicial Models of Local Government Legitimacy, 53 IND. L.J. 145, 172-73 (1977); Michael J. Waggoner, Log-Rolling and Judicial Review, 52 U. Colo. L. REV. 33, 42 n.26 (1980).

${ }^{84}$ See DunCAN KenNedy, A CRITIQUE OF ADJUDICATION 86 (1997); see generally Joel R. Cornwell, From Hedonism to Human Rights: Felix Cohen's Alternative to Nihilism, 68 TEMP. L. REV. 197 (1995) (exploring Felix Cohen's philosophy in contrast to contemporary nihilism); Martin P. Golding, Realism and Functionalism in the Legal Thought of Felix S. Cohen, 66 CORNELL L. Rev. 1031 (1982) (discussing Felix Cohen's written contribution to realist jurisprudence).

${ }^{85}$ Ch. 576, 48 Stat. 984 (1934) (codified as amended at 25 U.S.C. $\S \S 461-79$ (1934)); see also Documents of United States Indian Policy 223-25 (Francis Paul Prucha ed., 3d ed. 2000) (1975) (reprinting of the statute).

${ }^{86}$ Indian Reorganization Act, Ch. 576, § 16, 48 Stat. 987 (codified as amended at 25 U.S.C. $\S 476$ (1934)). Many battles over the authority of Indian tribal governments today deal with procedural versus substantive interpretations of the Indian Reorganization Act. See Elmer R. Rusco, A FATEFUL TiME: THE BACKGROUND AND LEGISLATIVE HisTORY OF THE INDIAN REORGANIZATION ACT (2000).

${ }^{87}$ FELIX S. COHEN, HANDBOOK OF FEDERAL INDIAN LAW (U.S. G.P.O. ed., 1942). 
The battle over campaign finance reform and campaign finance regulation questions whether American law accepts the view that the voting process serves as the means of totaling up the preferences of voters granting governmental power to the candidate or political party supported by the greatest number of voters, ${ }^{89}$ and thus protects the access of minorities and others to participate in this competitive process, ${ }^{90}$ or if it instead accepts the vision of Alexander Meiklejohn that "everything worth saying

${ }^{88}$ Ch. 959, 60 Stat. 1049 (1946). The ICCA was formerly codified at $\$ \S 70-70 \mathrm{v}-3$ of the United States Code, until omitted from the Code upon termination of the Commission on September 30, 1978. Act of Oct. 8, 1976, Pub. L. 94-465, § 2, 90 Stat. 1990 (providing for the dissolution of the Commission). Debates over the ICCA center on whether it was meant to merely provide a mechanism for settling historical and cultural differences between Indian tribes and American society, or whether it was meant to freeze into place a particular substantive agreement.

${ }^{89}$ For examples of this view, see JeREMY BENTHAM, A Fragment on Government (J.H. Burns \& H.L.A. Hart eds., 1988). See generally James M. BuchanAN \& GORDON TUlLOCK, THE CALCuluS OF CONSENT: LOGiCAL FoundaTiONS OF CONSTITUTIONAL DEMOCRACY (1962) (discussing democracy as the mere aggregation of preferences); JoSEPH SCHUMPETER, CAPITALISM, SOCIALISM, AND DEMOCRACY ( $3 \mathrm{~d}$ ed. 1950) (discussing democracy as the competitive process for acquiring the votes of the citizenry). For recent examples specifically discussing money in elections, see, for example, Lillian R. BeVier, Campaign Finance Reform: Specious Arguments, Intractable Dilemmas, 94 Colum. L. REV. 1258 (1994) (arguing against campaign finance reform because of the threat posed to freedom of the political process); Lillian R. BeVier, The Issue of Issue Advocacy: An Economic, Political and Constitutional Analysis, 85 VA. L. REV. 1761, 1763-65 (1999) (opposing the regulation of the political process through campaign finance reform); David Cole, First Amendment Antitrust: The End of Laissez Faire in Campaign Finance, 9 YALE L. \& POL'Y REV. 236, 245 (1991) (illustrating two sides to campaign finance reform); Bradley A. Smith, Faulty Assumptions and Undemocratic Consequences of Campaign Finance Reform, 105 YALE L.J. 1049, 1057-58 (1996) (dismissing the arguments in favor of campaign finance reform); Bradley A. Smith, Money Talks: Speech, Corruption, Equality and Campaign Finance, 86 GEO. L.J. 45 (1997) (arguing that campaign contributions and spending are a form of speech entitled to First Amendment protection); Bradley A. Smith, The Sirens' Song: Campaign Finance Regulation and the First Amendment, 6 J.L. \& POL'Y 1, 34-35 (1997) (dismissing campaign finance reform proposals put forth by various faculty); Kathleen M. Sullivan, Against Campaign Finance Reform, 1998 UTAH L. REV. 311 (discussing the categorization of political money as either act of speaking or voting); and Kathleen M. Sullivan, Political Money and Freedom of Speech, 30 U.C. DAVIS L. REV. 663, 671-75 (1997) (unraveling the arguments surrounding campaign finance reform).

${ }^{90}$ See Ely, supra note 80, at chs. 1-4 (1980); Peter Railton, Judicial Review, Elites, and Liberal Democracy, in Nomos XXV: Liberal Democracy 159 (J. Ronald Pennock \& John W. Chapman eds., 1983). This protection of access, of course, solely protects negative rights and prevents minorities from being excluded from the political process, rather than providing a substantive guarantee that they can affirmatively participate. Jesse ChOPER, Judicial ReVIEW AND the NATIONAL Political Process: A Functional ReConsideration of the Role of the Supreme Court 2 (1980); Richard Davies Parker, The Past of Constitutional Theory-And Its Future, 42 OнIO ST. L.J. 223, 230 (1981). This view, needless to say, is behind the "marketplace of ideas" notion of electoral speech. See Abrams v. United States, 250 U.S. 616, 630 (1919) (Holmes, J., dissenting) ("But when men have realized that time has upset many fighting faiths, they may come to believe even more than they believe the very foundations of their own conduct that the ultimate good desired is better reached by free trade in ideas - that the best test of truth is the power of the thought to get itself accepted in the competition of the market. ..."). See also AleXANDER MeIKLejohn, Free SPeEch And Its Relation to SelfGOVERNMENT (1948) (advocating the "marketplace of ideas" approach to freedom of speech). 
shall be said." ${ }^{11}$ The procedure versus substance debate is at the heart of battles over both environmental ${ }^{92}$ and criminal law. ${ }^{93}$

Given the centrality of this debate in various areas of law, Schneiderman is a helpful case to teach and include within the canon because it provides a particularly interesting way of looking at the procedure versus substance question (the "interest" element referred to earlier that Balkin and Levison generally neglect). First, Schneiderman examines procedure versus substance in a more compelling way than a case about filled milk does, ${ }^{94}$ because it discusses this debate as applied to a more interesting question: What does it mean to be an American and to believe in the United States Constitution? The case poses, in a particularly interesting way, the key issues at stake in battles over procedure versus substance. For example, a student might ask: Does accepting Justice Murphy's opinion in Schneiderman mean that the American Constitution has no content, and we are a nihilistic society? Chief Justice Stone's dissent in Schneiderman, a student might ponder, tends to equate the definition of our country with a particular substantive vision: What about those who disagree with this substantive vision? These are particularly interesting ways of getting at the issues in procedure versus substance discussions, and can be applied to other areas of law. The criminal law practitioner will consider the debate over the Justice Murphy and Chief Justice Stone opinions, which interested her greatly while she was a student, and she may apply this analysis to a case she is prosecuting or defending.

Burdens of proof play a big role in all areas of law, ${ }^{95}$ as they do in

${ }^{91}$ Alexander Meiklejohn, Political Freedom: The Constitutional Powers of the PeoPLE 26 (1960). For an example of a contemporary scholar who has accepted Meiklejohn's interpretation of the First Amendment, see Owen M. Fiss, The Irony of Free SPeEch (1996); see also CASS R. Sunstein, DEMOCRACY AND THE PRoblem Of FreE SPEECH (1993) (advancing a similar theory of free speech).

92 Robert D. BUllard, Dumping in Dixie: RaCe, Class, AND EnVIRONMENTAl Quality 7 (1990); Richard O. Brooks, A New Agenda for Modern Environmental Law, 6 J. ENVTL. L. \& Litig. 1, 26-27 (1991); Lawrence J. Straw, Environmental Justice: Racial Gerrymandering for Environmental Siting Decision, 14 VA. ENVTL L.J. 665, 667-70 (1995).

${ }^{93}$ Quite often, defendants contest the sentence they receive under the "cruel and unusual punishment" provision of the U.S. Constitution. U.S. CONST. amend. VIII. There is a debate about whether this and other elements of criminal procedure are about procedure rather than substance. See, e.g., Joshua Dressler, Understanding Criminal Procedure 2 (3d ed. 2002); Sherry F. Colb, The Qualitative Dimension of Fourth Amendment "Reasonableness," 98 COLUM. L. REV. 1642 (1998) (arguing that the Fourth Amendment reasonableness requirement should contain both substantive and procedural safeguards). For instance, is the law governing sentencing all about making sure that jurors and judges consider certain factors, or is it about generating certain substantive outcomes (certain sentences, for example)?

${ }^{94}$ United States v. Carolene Prods. Co., 304 U.S. 144 (1938) (examining the question of procedure versus substance in terms of the violation of the Filled Milk Act of Congress of March 1923). ${ }^{95}$ For a discussion of this notion, see, for example, Lawrence M. Solan, Refocusing the Burden of Proof in Criminal Cases: Some Doubt about Reasonable Doubt, 78 TEX. L. REV. 105 (1999). Burdens of proof, of course, have both normative and empirical components. The normative component of a burden of proof is that a particular burden may be created because we want to favor one outcome over 
Schneiderman. In constitutional law, for instance, any lawyer who must argue a case involving a governmental classification must know the "strict scrutiny" standard required for a racial classification to be upheld. ${ }^{96}$ Determining the appropriate "burden of proof" or legal standard is important in deciding almost all cases in law, just as it was important in deciding Schneiderman. Law students studying Schneiderman can see how to handle the burden of proof issue within a particular case. Justice Murphy's majority opinion held that there had to be overwhelmingly strong justification and proof for a naturalized citizen to have their citizenship revoked. ${ }^{97}$ This burden of proof meant that the majority did "not decide what interpretation of the [Communist] Party's attitude toward force and violence is the most probable on the basis of the present record, or that petitioner's testimony is acceptable at face value." ${ }^{.98}$ Instead, according to the majority, the Court held only that:

[W] here two interpretations of an organization's program are possible, the one reprehensible and a bar to naturalization and the other permissible, a court in a denaturalization proceeding assuming that it can re-examine a finding of attachment upon a charge of illegal procurement, is not justified in canceling a certificate of citizenship by imputing the reprehensible interpretation to a member of the organization in the absence of overt acts indicating that such was his interpretation. ${ }^{99}$

Thus, Justice Murphy decided that the government, trying to denaturalize Schneiderman, had the burden of proof.

What does a lawyer do when faced with having the burden of proof? Fear not, young law student or lawyer-Schneiderman is a great example

another, or because it would be particularly damaging if one side won. In Schneiderman, for instance, it would be catastrophic for Schneiderman if he lost, and therefore as a normative matter the Schneiderman Court created the burden of proof that it did. The empirical aspect of burdens of proof is that, in a world of limited information, we can make certain factual generalizations (for example, more often than not a certain thing is true), and therefore in a particular case we can presume it is true unless it is clearly proven otherwise. The tort doctrine of res ipsa loquitur falls into this category. Cf. Mark F. Grady, Res Ipsa Loquitur and Compliance Error, 142 U. PA. L. REV. 887 (1994) (discussing res ipsa loquitur as a means of avoiding complicated and confusing factual presentations at trial).

Given the centrality of burdens of proof to law in general (and to constitutional law in particular), it is certainly a good idea to make the concept of burdens of proof part of a constitutional law class, and Schneiderman is a good way to teach them; the case is interesting, and (as quite often occurs in the world of practice), there are competing burdens of proof - in this case, the conceptions of Justice Murphy's versus Chief Justice Stone's.

${ }^{96}$ See Peter J. Rubin, Reconnecting Doctrine and Purpose: A Comprehensive Approach to Strict Scrutiny after Adarand and Shaw, 149 U. PA. L. REV. 1, 12-15 (2000).

${ }^{97}$ United States v. Schneiderman, 320 U.S. 118, 122 (1943).

${ }^{98} \mathrm{Id}$. at 158 .

${ }^{99} \mathrm{Id}$. at 153 . 
of what to do in these situations. Chief Justice Stone's dissent presents another relevant standard of proof-where the Court reviewed a lower court's decision to revoke Schneiderman's citizenship, ${ }^{100}$ the Court should affirm such a decision unless there was clear evidence to the contrary. Thus, the Murphy-Stone debate illustrates the very common legal phenomenon of dueling burdens of proof. ${ }^{101}$

Also present in Schneiderman, and in much of constitutional and other areas of law, is the interplay of constitutional law with complicated statutory law. ${ }^{102}$ Schneiderman gives law students a sense of how to handle

${ }^{100} I d$. at 170 (Stone, C.J., dissenting).

${ }^{101}$ Dueling burdens of proof suggests a degree of uncertainty in deciding cases that might be an appropriate way to introduce critical legal studies and its role in constitutional thinking. MARK V. Tushnet, ReD, White AND BluE: A CRitical ANALysis of Constitutional LAW (1988).

${ }^{102}$ There is a surprising lack of dialogue between the scholars and practitioners of constitutional law and the scholars and practitioners of statutory interpretation. This disjunction has several manifestations. In the world of law review articles, many prominent constitutional law articles appear to use familiar statutory interpretation techniques, without explicitly discussing this process. They therefore miss out on an accumulated body of practice from statutory interpretation. For instance, Akhil Reed Amar's wonderful article on intratextualism only briefly discusses that scholars, judges, and lawyers in statutory interpretation have used his technique for hundreds of years. See Akhil Reed Amar, Intratextualism, 112 HARV. L. REV. 747, 765 n.72 (1999) (discussing how his style of analysis "can be used as a technique of statutory as well as constitutional interpretation"). Amar notes that:

intratextualism can be used in statutory interpretation as well as in constitutional law. Indeed, Professors Eskridge and Frickey have [discussed this technique]. I shall not here attempt serious analysis of statutory intratextualism. Some of the arguments I have offered-focusing on the Constitution as a compact, cleanly bounded, and easily accessible document, written for ordinary people and designed to endure over centuries - may not readily transfer to the realm of statutory interpretation. And in surveying canonical cases and commentaries, I have intentionally focused on issues of constitutional as opposed to statutory interpretation.

$I d$. at $801 \mathrm{n} .204$ (citations omitted).

In constitutional law classes and casebooks, there is an insufficient amount of attention devoted to the ongoing debates about interpretive technique in statutory interpretation; one has to look long and hard to find references to the ongoing debate between William Eskridge, Justice Antonin Scalia, and others about the proper modality of statutory interpretation. For examples of this debate, see WiLLIAM N. ESKRIDGE, JR., DYNAMic StATUTORY InTERPRETATION (1994), and Jonathan R. Siegel, The Use of Legislative History in a System of Separated Powers, 53 VAND. L. REV. 1457 (2000). The same goes for statutory interpretation classes and textbooks - there is an insufficient amount of attention devoted to the longstanding and illuminating debate about the proper theory of constitutional interpretation. There are exceptions, of course. Some articles look at what the Constitution tells us about how we should interpret statutes. E.g., William N. Eskridge, Jr., All About Words: Early Understandings of the "Judicial Power" in Statutory Interpretation, 1776-1806, 101 Colum. L. REV. 990 (2001); John F. Manning, Deriving Rules of Statutory Interpretation from the Constitution, 101 COLUM. L. REV. 1648 (2001). Some articles consider the role of constitutional norms in statutory interpretation. E.g., William N. Eskridge, Jr., Public Values in Statutory Interpretation, 137 U. PA. L. REV. 1007 (1989); Nick Levin, Constitutional Statutory Synthesis, ALA. L. REV. (forthcoming 2003); Ira Lupa, Statutes Revolving in Constitutional Law Orbits, 79 VA. L. REV. 1 (1993). Several scholars have written articles on statutory interpretation that do not mention constitutional law, and have also written pieces in constitutional law that do not mention statutory interpretation. Although there is no direct interface between statutory/constitutional interpretive thought in the text of their articles, at least the same person is studying both areas (Eskridge and Daniel Farber would be examples of scholars fitting this description). E.g., William N. Eskridge, Jr., Destabilizing Due Process and Evolutive Equal Protection, 47 UCLA L. 
cases that involve various levels and types of law-statutory law, constitutional text, lower court opinions - and in particular, how to handle statutory law in a context similar to the facts of Schneiderman. The various opinions illustrate many of the techniques of statutory interpretation. Justice Murphy, for instance, used legislative history as a tool of statutory interpretation in his majority opinion. Justice Murphy relied on the fact that Congress had later changed the requirement for attachment to the Constitution from one of behavior, to a demonstration of an applicant's "good moral character, attached to the principles of the Constitution."103 Quoting an important representative's comment that the new statute involved substantive changes "with a view to preventing persons who have no real attachment to the United States from enjoying the high privilege of American nationality," 104 Justice Murphy added that "[t]his remark suggests that the change from 'behaved as a man attached' to 'has been and still is a person attached' was a change in meaning." 105

Schneiderman is also an excellent means of teaching statutory interpretation canons and Karl Llewellyn's notion of "opposing canons." 106 Justice Murphy invoked a statutory interpretation canon, the familiar canon that statutes should be construed to avoid constitutional doubts, ${ }^{107}$ a popular canon with the current Court. ${ }^{108}$ Justice Murphy argued that taking away Schneiderman's citizenship without a very high level of proof might raise constitutional problems, and thus the Court should refrain from doing so. ${ }^{109}$ Justice Murphy also overturned the lower court decisions because of potential First Amendment problems arising from punishing citizens for their

REV. 1183 (2000) (constitutional law); William N. Eskridge, Jr., Norms, Empiricism and Canons in Statutory Interpretation, 66 U. CHI. L. REV. 671 (1999) (statutory interpretation); Daniel A. Farber, Speaking in the First Person Plural: Expressive Associations and the First Amendment, 85 MinN. L. REV. 1483 (2001) (constitutional law); Daniel A. Farber, Do Theories of Statutory Interpretation Matter? A Case Study, 94 Nw. U. L. REV. 1409 (2000) (statutory interpretation).

${ }^{103}$ United States v. Schneiderman, 320 U.S. 118, 121 (1943).

${ }^{104} \mathrm{Id}$. at 134 .

${ }^{105} \mathrm{Id}$.

${ }^{106}$ Karl Llewellyn, Remarks on the Theory of Appellate Decision and the Rules or Canons About How Statutes Are to Be Construed, 3 VAND. L. REV. 395, 401 (1950) (explaining the dual nature of the canons of statutory construction).

${ }^{107}$ E.g., NLRB v. Catholic Bishop, 440 U.S. 490, 501 (1979) (construing a statute to avoid constitutional doubts); United States ex rel. Attorney Gen. v. Del. \& Hudson Co. 213 U.S. 366, 407 (1909) (same).

${ }^{108}$ Zadvydas v. Davis, 533 U.S. 678, 679 (2001) (holding that indefinite detention of an alien would raise constitutional issues); Solid Waste Agency of N. Cook County v. United States Army Corps of Eng'rs, 531 U.S. 159, 161 (2001) (reading the migratory bird rule of the Clean Water Act to avoid significant constitutional and federalism questions); Jones v. United States, 529 U.S. 848, 849 (2000) (holding that application of federal arson statute to a residence exceeded authority of Congress under the Commerce Clause and that to read otherwise would raise constitutional issues). But $c f$. William K. Kelley, Avoiding Constitutional Questions as a Three-Branch Problem, 86 CORNELL L. REV. 831 (2001) (criticizing this canon).

${ }^{109}$ United States v. Schneiderman, 320 U.S. 118, 122 (1943). 
ideas, ${ }^{110}$ an argument expanded upon in greater detail in Justice Douglas's concurrence:

If $\S 15$ should be broadened by judicial construction to permit the findings of attachment to be set aside for reasons other than fraud, then the issue of illegality would be made to turn not on the judge being satisfied as to applicant's attachment but on the evidence underlying that finding . . . . But where it has not done so in plain words, we should be loathe to imply that Congress sanctioned a procedure which in absence of fraud permitted a man's citizenship to be attacked years after the grant because of his political beliefs, social philosophy, or economic theories. We should not tread so close to the domain of freedom of conscience without an explicit mandate from those who specify the conditions on which citizenship is granted to or withheld from aliens. ${ }^{111}$

Thus, Justice Douglas allowed Schneiderman to remain a citizen so that the constitutional protection of freedom of speech ${ }^{112}$ would not be implicated.

Schneiderman can teach the lawyer in training how to respond to Justice Murphy's argument: Use your own canon of interpretation! Chief Justice Stone's dissent seems to use an "absurd result" canon, ${ }^{113}$ thereby attempting to avoid an interpretation of the statute that would lead to a seemingly illogical or strange result that Congress could not have intended:

It would seem passing strange that Congress-which authorized cancellation of citizenship under $\S 15$ for failure to hold the naturalization hearing in open court instead of in the judge's chambers, or for failure to present the requisite certificate of arrival in this country - should be thought less concerned with the applicant's attachment to the principles of the Constitution and that he be well disposed to the good order and happiness of the United States. For what could be more important in the selection of citizens of the United States than that the prospective citizen be attached to the principles of the Constitution. ${ }^{114}$

\footnotetext{
${ }^{110}$ Id. at $137,144$.

${ }^{111} I d$. at 163, 165 (1943) (Douglas, J., concurring).

${ }^{112}$ U.S. CONST. amend. I ("Congress shall make no law respecting an establishment of religion, or prohibiting the free exercise thereof; or abridging the freedom of speech, or of the press; or the right of the people peaceably to assemble, and to petition the Government for a redress of grievances.").

${ }^{113}$ See, e.g., Clinton v. New York, 524 U.S. 417, 455 (1998) (Scalia, J., dissenting) (mentioning the canon); Green v. Bock Laundry Mach. Co., 490 U.S. 504, 509-10 (1989) (invoking the canon). See also Veronica M. Daugherty, Absurdity and the Limits of Literalism: Defining the Absurd Result Principle in Statutory Interpretation, 44 AM. U. L. REV. 127 (1994) (elaborating on this canon).

${ }^{114}$ Schneiderman, 320 U.S. at 175-76 (Stone, C.J., dissenting) (citations omitted).
} 
The Murphy-Stone utilization of differing statutory interpretation canons is a wonderful illustration of the dueling canons notion.

Even beyond legal doctrine, Schneiderman illustrates a number of other items implicated by legal practice that lawyers should learn and understand. First, the opinions of the judges at all levels in the Schneiderman case demonstrate the promises, perils and best and worst ways to use nonlegal materials as evidence. In order to define Schneiderman's viewpoints, all judges had to grapple with Communist Party materials. The majority at the Supreme Court level examined the Communist Party materials and refused to accept as dispositive evidence the statements of "certain alleged Party principles and statements by Party Leaders which are said to be fundamentally at variance with the principles of the Constitution." 115 Instead, it emphasized "that under our traditions beliefs are personal and not a matter of mere association, and that men in adhering to a political party or other organization notoriously do not subscribe unqualifiedly to all of its platforms or asserted principles." 116 Chief Justice Stone examined Communist Party materials in great detail as well, as reflected by his dissenting opinion, ${ }^{117}$ and indeed some of these materials were included as an appendix to the opinion of the Court. ${ }^{118}$ Discussing the judicial and lawyerly use of these materials is an excellent way to teach future lawyers about the most effective use of evidence. After all, in the post-footnote eleven world, ${ }^{119}$ non-legal materials are increasingly relevant in cases of all sorts, including constitutional law cases.

The Schneiderman case also can serve as a wonderful basis from which to start a discussion on the role some non-legal aspects of cases play in the judicial decision making process. Thus, Schneiderman can serve as a good member of the "illustrative pedagogical canon." In other words, the case can demonstrate certain lessons that lawyers should learn about in constitutional and other areas of law, while not involving discussions of doctrine and other formal legal rules. It is beyond argument that the idiosyncrasies of particular judges - their personalities, political attitudes, relationships with their colleagues - can impact the decisions that they issue, an insight

${ }^{115} \mathrm{Id}$. at 136 .

${ }^{116} \mathrm{Id}$.

${ }^{117}$ See id. at 182-97 (Stone, C.J., dissenting).

${ }^{118} I d$. at app.

${ }^{119}$ Brown v. Bd. of Educ., 347 U.S. 483, 494 n.11 (1954) (examining non-legal aspects of discrimination and segregation); see, e.g., PAUl L. Rosen, THE SUPREME CourT AND SOCIAL SCIENCE 134-72 (1972) (defending the use of social science as a continuation of the sociological jurisprudence of Justice Louis Brandeis, Justice Benjamin Cardozo and Dean Roscoe Pound); THE UsE/NonUSE/Misuse OF Applied Social Research in the CourTs (Michael J. Saks \& Charles H. Baron eds., 1980) (providing an overview of the way social science research has been used by the courts and the ways in which this use has been criticized); Kenneth L. Karst, Legislative Facts in Constitutional Litigation, 1960 SUP. CT. REV. 75 (examining the role of "facts" in the creation of constitutional law). 
that has been developed by the attitudinal revolution. ${ }^{120}$ Yet the new institutionalism in political science and public law ${ }^{121}$ does not appear in a single major constitutional law casebook nor in constitutional law classes. ${ }^{122}$ The issues in Schneiderman provoked an extensive battle within the Court. J. Woodford Howard, the political scientist and biographer of Justice Murphy, described Schneiderman as "one of the decade's most ideologically divisive cases" 123 as members of the Court, fueled by "unusual emotionalism," "124 debated the issues the Court faced. The Schneiderman decision was issued in 1943, a period when the Supreme Court was characterized by numerous internal battles. ${ }^{125}$

During Solicitor General Fahy's presentation, the division between the Justices became apparent, and the need for and shape of internal coalition building became evident. Justice Felix Frankfurter asked whether the Communist Party had any clear principles, to which Justice Black responded that "[t]he Hearst press will love that question." 26 Justice Frankfurter responded, "I don't give a damn whether the Hearst press or any other press likes or dislikes any question that seems to me relevant to the argument. I am a judge and not a politician." ${ }^{27}$ Justice Black angrily replied that "[of] course...you, unlike the rest of us, live in the stratosphere." 128

This division between Justices Black and Frankfurter during oral arguments presaged later divisions between the two Justices in conference and in the opinions of the Court. During conference on December 12, Justice Douglas stated that if "Schneiderman himself was committed to an

\footnotetext{
${ }^{120}$ For some of the key works in this area of social science research on courts, see JEFFREY A. Segal \& Harold J. Spaeth, The Supreme Court AND the AtTitudinal Model (1993); Harold J. Spaeth, An Approach to the Study of Attitudinal Differences as an Aspect of Judicial Behavior, 5 MIDWEST J. POL. SCI. 165 (1961); S. Sidney Ulmer, The Analysis of Political Behavior on the United States Supreme Court, 22 J. POL. 629 (1960). For a discussion of the background of this literature, see generally FrONTIERS OF JUdiCiAl RESEARCH (Joel B. Grossman \& Joseph Tanenhaus eds., 1969); WALTER F. Murphy and C. Herman PRitchett, COURTs, Judges and Politics, AN INTROduction to the Judicial Process (4th ed. 1986); David Rohde \& Harold J. Spaeth, Supreme Court Decision MAKING (1976); and Tracey E. George, Developing a Positive Theory of Decisionmaking on U.S. Courts of Appeals, 58 OHIO ST. L. J. 1635 (1998).

${ }^{121}$ E.g., Supreme Court Decisionmaking: New Institutionalist Approaches (Cornell W. Clayton \& Howard Gillman eds., 1999); Keith E. Whittington, Once More Unto the Breach: PostBehavioralist Approaches to Judicial Politics, 25 LAW \& SOC. INQUIRY 601, 608-16 (2000).

${ }^{122}$ Of the major constitutional texts discussed supra at note 12 , none devote a section or any significant amount of text to what the social sciences can teach students in a constitutional law class.

${ }^{123}$ J. WOOdFord Howard, JR., Mr. JUSTICE MuRPHY: A POLITICAL BIOGRAPHY 309 (1968).

${ }^{124}$ Id. at 311 .

${ }^{125}$ James F. Simon, The Antagonists: Hugo Black, Felix Frankfurter, AND Civil LiberTIES IN MODERN AMERICA (1989).

${ }^{126}$ LASH, supra note 37, at 209.

${ }^{127} \mathrm{Id}$.

${ }^{128} \mathrm{Id}$.
} 
immediate program of action by force and violence" ${ }^{129}$ he would feel differently. Justice Murphy, sensing that Justice Douglas and a number of other Justices would side with Justice Black (and therefore that Justice Frankfurter would not), circulated a draft opinion on May 31, 1943, responding to Justice Douglas's comments in conference and attempting to create a majority coalition to overturn the lower court decisions. ${ }^{130}$ Any thoughts that Justice Murphy had of trying to gain a larger majority than the 5-3 margin he believed he had was dashed by a note that Justice Frankfurter sent Justice Murphy after Justice Murphy circulated his draft opinion. Justice Frankfurter suggested that the headnote to the Justice Murphy opinion read:

The American Constitution ain't got no principles. The Communist Party don't stand for nuthin.' The Soopreme Court don't mean nuthin'. Nuthin' means nuthin,' and ter Hell with the U.S.A. so long as a guy is attached to the principles of the U.S.S.R. ${ }^{131}$

This coalition building strategy of Murphy is a great lesson about the internal, collegial dynamics of judicial decision-making, and a subject that future lawyers should study. In order to be maximally effective advocates, future lawyers should be aware that the social background ${ }^{132}$ of judges matters, another insight of political science scholarship on public law. In Schneiderman, the personal background of Justice Frankfurter greatly influenced his stance on the meaning of "attached to the principles of the Constitution." During the Court's conference on December 5, Frankfurter spoke about the importance of his personal experience in shaping his eventual vote on the legal issues:

I am saying what I am going to say because this case arouses in me feelings that could not be entertained by anyone else around this table. It is well known that a convert is more zealous than one born to the faith. None of you has had the experience I have had with reference to American citizenship....

[Attachment to the Constitution] is a historic phrase and it certainly is not empty of all meaning - just rhetorical flour-

\footnotetext{
${ }^{129}$ Id. at 215 .

${ }^{130} I d$. at 248-49.

${ }^{131}$ HOWARD, supra note 123 , at 315 .

${ }^{132}$ For examples of excellent articles looking at the role that social background played in a judge's thinking about a particular case, see Ulf Torgensen, The Role of the Supreme Court in the Norwegian Political System, in Judicial Decision-MaKing 221 (Glendon Schubert ed., 1963); John R. Schmidhauser, The Justices of the Supreme Court: A Collective Portrait, 3 MIDWEST J. POL. SCI. 1 (1959).
} 
ish-and it certainly does not mean you are attached to the principles of the Constitution if you want to overthrow the scheme of society of which the Constitution is a framework simply because one of the principles of the Constitution is the right to amend it. In other words, one can hardly be attached to the principles of the Constitution merely because one is ready to undo the Constitution and the Constitution affords a means of doing so. ${ }^{133}$

Justice Frankfurter eventually joined the dissenting opinion of Chief Justice Stone. ${ }^{134}$

Schneiderman features several particularly thoughtful examples of legal reasoning, and thus can teach law students about how to make good legal arguments. All of the opinions and briefs use a combination of statutory textualism, statutory originalism, constitutional textualism, and constitutional originalism; this eclectic form of statutory and constitutional argumentation is the most effective yet understudied and challenging form of constitutional argument. ${ }^{135}$

The Schneiderman case illustrates the inevitable political pressures and components of many cases. First, as Mary Dudziak's recent book ably demonstrates, ${ }^{136}$ foreign policy concerns can sometimes impact the disposition of cases and the evolution of doctrine. In the years leading up to the Court hearing Schneiderman, particularly between 1939 and 1942, American-Soviet relations had changed dramatically. The Schneiderman case was initially argued during February of 1942, but Secretary of State Summer Welles asked the Court to temporarily postpone the case so as not to worsen relations with the Soviet Union. ${ }^{137}$ The United States had recently recognized the Soviet Union, and the Soviets would prove to be crucial partners in the battle against the Germans and Japanese. Welles argued that revoking Schneiderman's citizenship because of his obvious Communist Party sympathies would worsen relations with the Soviets. As a result, in response to Welles's request, the Court delayed oral arguments to November 9, 1942. Undoubtedly, foreign policy concerns weighed on the Justices' minds even beyond that date, although the Court attempted to dismiss any notions that foreign policy concerns mattered when it insisted in its majority opinion that American "relations with Russia . . . are immaterial to a decision of this case." 138

\footnotetext{
${ }^{133}$ LASH, supra note 37, at 211-12.

${ }^{134}$ United States v. Schneiderman, 320 U.S. 118, 197 (1943).

${ }^{135} C f$. William N. Eskridge, Jr., Dynamic Statutory InTERPRETATion (1994) (examining this form of argument in statutory interpretation).

${ }^{136}$ Mary L. DudziaK, Cold War Civil Rights, Race AND the Image of American DemocRACY (2000).

${ }^{137}$ HOWARD, supra note 123 , at 310 .

${ }^{138}$ Schneiderman, 320 U.S. at 119.
} 
B. The Cultural Literacy Canon and Schneiderman

Schneiderman undoubtedly furthers all of the pedagogical goals discussed above. However, the most compelling reasons for including Schneiderman in the constitutional canon-and thus adding it to constitutional law syllabi-stem less from the case's effectiveness in informing students about the doctrines and skills needed to be good lawyers, than from the case's importance to anyone interested in creating the optimal cultural literacy canon and thereby creating law students (and lawyers) who are well informed about key episodes in American constitutional development. These important episodes have become even more central to the American constitutional experience since September 11.

The lawyer, as a servant of the law, must be able to discuss what it means to believe in the central document of the American experience, the Constitution-a discussion even more important during the era of increased international conflict that has followed September 11th. Also, during a time when political pressure on courts to restrict civil liberties is relatively high, lawyers must be able to discuss past instances of courts exerting their independence and protecting civil liberties. This is especially true in the case of Schneiderman, which was one of a handful of wartime cases with an enormous practical impact - a practical impact felt by the same group of individuals (immigrants) garnering so much attention after September 11. Finally, at a time when thousands of immigrants are being detained, and when the nation is pursuing some of the broadest immigration reforms in a decade, lawyers must know about the history of the constitutional law of immigration policy, and what I call the "immigration Constitution" "139 - the impact that immigration policy and law has had on American constitutional development.

First of all, the contextualization of the canon that I discussed earlier means that constitutional law classes today should be very different from constitutional law classes years ago, or for that matter from constitutional law classes on September 10, 2001. Since the events of September 11, 2001, the meaning of American national identity has taken on new salience. Defining what the country is fighting against and is opposed to has

\footnotetext{
${ }^{139}$ As I shall discuss below, I mean by this that the history of immigration regulation has had two profound effects on American constitutional development. First, immigration policies have had an enormous impact on the demographic, economic, and ideological makeup of American society, which obviously has had ramifications for American constitutional development. Second, immigrants have been a major portion of American society for some time, and therefore the extent of constitutional protection they have enjoyed is a crucial-yet largely ignored-issue.
} 
recently taken on great relevance. The events of September 11 and its aftermath have forced the country to ask what it believes in, what regimes it opposes, and what it is that ties us together. Certainly, these questions as applied to the meaning of the Constitution have always been relevant questions that lawyers should be prepared to discuss. The notion of a Constitution that "constitutes" us presupposes that such a written document will be central to defining our nation. After all, the Constitution is the central document of the American "civil religion," 140 and Schneiderman is a compelling case because it goes into great detail to examine what it means to believe in that document.

Yet these questions, properly understood in accordance with my discussion of the contextualization of the canon, have become of great importance in the last few years, even before the events of September 11. Prior to September 11, minority groups constituted twenty-five percent of the United States population, and at least eleven major United States cities are already majority-minority. ${ }^{141}$ By the year 2040 , it is expected that nonHispanic whites, who composed eighty-five percent of the population in 1900, will comprise approximately fifty percent of the American population. ${ }^{142}$ As a result of changes in immigration laws, ${ }^{143}$ immigration to the United States has been transformed in virtually every aspect since 1965 . These changes in immigration laws have led to a new type of American immigrant, one whose presence has changed the "look and feel" of a traditionally overwhelmingly white American society. Yet these dramatic social changes have had almost no impact on the materials taught in American constitutional law classes. ${ }^{144}$

\footnotetext{
${ }^{140}$ For a description of the symbolic significance of the Constitution, see Max Lerner, Constitution and Court as Symbols, 46 YALE L.J. 1290 (1937).

${ }^{141}$ William P. O'Hare, America's Minorities-The Demographics of Diversity, POPULATION BuLL., 2, 9-27 (1992).

${ }^{142}$ Michael Fix \& Jeffrey S. PAssel, Immigration and Immigrants: Setting the ReCord STRAIGHT 27-28, 38-43 (1994).

${ }^{143}$ The 1965 Immigration Act eliminated race and national origin (more or less) as a basis for determining whether an applicant to live in the United States should be admitted. This change was a major development for American immigration law. American immigration law had been overtly race conscious from the first federal regulation of immigrants. See Act of Mar. 26, 1790, ch. 3, 1 Stat. 103, 103-04 (infusing immingration policy with racial considerations). Since 1965, over seventy-five percent of immigrants to the United States have been from Asia, Africa, or Central or South America. inS, United States Department of Justice, Statistical Yearbook of the INS 30 (1991); BUREAU of the Census, United States Department of Commerce, Historical Statistics of the UNited STATES, COLONIAL TIMES TO 1970, 105-09 (1976).

${ }^{144}$ Cases that clearly arose because of increasingly ethnic diversity (e.g., cases dealing with different religions practices) are addressed in constitutional law classes and casebooks merely for their doctrinal significance (i.e. what does this mean for freedom of religion and the First Amendment) rather than for what they say about multiculturalism and the future of the American Constitution.
} 
All of these demographic changes have occurred in a relatively short period of time, generating cultural, economic, and social anxieties among many Americans, who, even before September 11, began to ask with renewed interest what it means to be an American. A core part of that discussion undoubtedly centers on what the central document of our country, ${ }^{145}$ the Constitution, is all about. As members of the small group of Americans who have extensively studied the Constitution, and (for some law students ${ }^{146}$ ) as members of the even smaller group of Americans who litigate cases under that document and continue to define its content, all law students and future lawyers should begin to ask themselves anew what it means to believe in the central document of the American civil religion. No case illustrates this question and its complexity better than Schneiderman.

Schneiderman is more than a proto-First Amendment case, more than a case that can be viewed as synonymous with other cases litigating First Amendment rights in the age of World War II and the Cold War. Justice Murphy's opinion does use the First Amendment and its values as inspiration for his opinion, ${ }^{147}$ however, the debate between Justice Murphy and dissenting Chief Justice Stone is about much more than that. It is about the very essence or core of the Constitution and what it means to believe in that document.

Law students studying Schneiderman will have a renewed ability to talk to others outside of the legal profession about what the Constitution is and what it means to believe in such a document, a matter of general importance because of multiculturalism as well as because of September 11.

Second, during this time of war, it is important for lawyers to be able to talk to the general public about the autonomy, or at least the relative autonomy, of law and the courts, ${ }^{148}$ from politics and other matters, even during wartime, ${ }^{149}$ and even when it comes to protecting fragile civil liberties. Law students need to be able to cite a case that preserved civil liberties against political pressure during wartime to counter those more prominent cases where courts did not protect civil liberties against political pres-

${ }^{145}$ Supra note 140.

${ }^{146}$ Supra notes 18 and 25.

${ }^{147}$ United States v. Schneiderman, 320 U.S. 118, 137-44 (1943).

148 See Richard A. Posner, The Decline of Law as an Autonomous Discipline: 1962-1987, 100 HARV. L. REV. 761 (1987) (discussing the changes in the legal system and legal thought that began during the 1960's).

149 This is because, although the U.S. Constitution itself contains very few emergency provisions, see U.S. ConST. art. I, $\S \S 8,9$ (giving Congress the power "[to call] forth the Militia to execute the Laws of the Union, suppress Insurrections and repel Invasions" and to suspend the writ of habeas corpus "when in Cases of Rebellion or Invasion the public Safety may require it"), it does permit governmental institutions to exercise greater power than they would be able to during times of peace. Home Bldg \& Loan Ass'n v. Blaisdell, 290 U.S. 398, 426 (1934) (holding that "while emergency does not create power, emergency may furnish the occasion for the exercise of power"). 
sure, especially because Schneiderman can serve that role for World War II. World War II was one of the few wars that Americans know intimately, and Schneiderman had a substantial practical impact. Such knowledge can show law students and lawyers - and therefore the general public - that courts can realistically, and effectively, protect civil liberties during wartime.

Most of the "greatest hits" of American wartime constitutional lawKorematsu v. United States, ${ }^{150}$ Hirabayashi v. United States, ${ }^{151}$ and Ex parte $M c$ Cardle ${ }^{152}$ - all involved the Supreme Court caving to political pressure and approving restrictions on civil liberties, in a manner that made courts seem weak and unable to protect civil liberties. More recently, the case of Ex parte Quirin ${ }^{153}$ has received substantial attention and has therefore been added to this greatest hits list of American wartime constitutional law, despite the fact that this case might be the most embarrassing example of courts caving to political pressure during wartime. ${ }^{154}$ These cases are not usually presented in constitutional law casebooks, and when they do appear in casebooks they are not yoked together ${ }^{155}$ with cases demonstrat-

${ }^{150} 323$ U.S. 213 (1944).

151320 U.S. 81 (1943).

15274 U.S. 506 (7 Wall.) (1868).

${ }_{153} 317$ U.S. 1 (1942).

${ }^{154}$ On June 27, 1942, the Federal Bureau of Investigation ("FBI") announced that it had arrested eight German saboteurs, all of whom landed on American soil carrying explosives and were under orders to destroy American military targets. See Harvey Ardman, at http://www.uhuh.com/ laws/donncoll/eo/1942/EO2.TXT (last visited Oct. 19, 2002) (on file with the Connecticut Law Review). Within a week of their arrest, President Franklin Delano Roosevelt ordered the arrested Germans tried before a secret military tribunal, and also denied the Germans access to the American civilian courts. Ex Parte Quirin, 317 U.S. at 21-24. Even before the trial ended (it lasted a total of three weeks), the Germans' appointed defense counsel sought habeas corpus relief. Id.

With the case at the Court, and a President unlikely to obey a Supreme Court order that went against him in the White House, Chief Justice Harlan Fiske Stone and the rest of the Court announced that they had upheld the military tribunal within two days of hearing the case. Jonathan Turley, The Dark History of a Military Tribunal: Quirin Revisited, NAT'L L.J. (Nov. 1, 2002), available at www.law.com/jsp/article.jsp?id=1032128862731 (last visited Nov. 21, 2002) (on file with the Connecticut Law Review). The Court promised that a full opinion would be issued later. Id. The opinion was issued after several of the Germans had already been executed and it avoided many of the key legal issues in the case. $I d$.

There are many examples of courts bowing to political pressure during times of war beyond those instances discussed in the Article. For instance, in World War I, the country imprisoned various individuals for several years simply for speaking out against the American war effort. See Abrams v. United States, 250 U.S. 616 (1919); Debs v. United States, 249 U.S. 211 (1919); Frohwerk v. United States, 249 U.S. 204 (1919); Schenck v. United States, 249 U.S. 47 (1919). During the Cold War, thousands of individuals lost their jobs, were subject to federal investigations, or were sent to prison because of their affiliation with the Communist Party. E.g., Dennis v. United States, 341 U.S. 494 (1951); Michal R. Belknap, Cold War Political Justice: The Smith Act, the Communist PARTY, AND AMERICAN CiVIL LiberTies (1977); Victor S. NAVASKy, NAMING NAMES (1980); ARthur J. SABin, In CALMER Times: The Supreme CourT AND Red MONDAY (1999).

${ }^{155}$ I borrow this concept from Richard Primus's excellent article explaining the interdependency of cases based on their respective canonical and anti-canonical text. Primus, supra note 13, at 248. 
ing courts standing up to political pressure and protecting civil liberties in a time of war. The above mentioned cases are painful reminders that, in times of war, courts often do not protect citizens against incursions on civil liberties and act in ways that we often later regret. ${ }^{156}$ How can citizens of this country, familiar with only this short greatest hits list, have confidence in our courts in the post-September 11 world?

Part of the answer undoubtedly involves devoting attention to the handful of cases since September 11 in which American courts have demonstrated a surprising degree of independence. ${ }^{157}$ The answer additionally

${ }^{156}$ The battle to overturn the legacy of Japanese exclusion has gone on since the end of World War II. The Evacuation Claims Act of 1948 provided minimal compensation for economic losses but required substantial evidence as proof for claims of such losses suffered during the Japanese exclusion. 50 U.S.C app. $\S \S 1981-1987$ (1994). Furthermore, this statute did not reimburse victims for lost income or for general pain and suffering. Id. In 1954, Congress finally reinstated several JapaneseAmericans to their positions in the U.S. Postal Service. Act of July 15, 1952, Pub. L. No. 82-545, 66 Stat. 634-35 (1953). In 1972, Congress passed an amendment to the Social Security Act giving Japanese-Americans retirement credit for the time they were interned. 42 U.S.C. § 431 (2000).

The most well known attempts to secure judicial redress for the Japanese internments began in the 1980s. One line of activity led to overturning the convictions for the various defendants named in the internment cases that the Supreme Court decided. Hirabayashi v. United States, 828 F.2d 591, 594, 608 (9th Cir. 1987); Korematsu v. United States, 584 F. Supp. 1406, 1409, 1420 (N.D. Cal 1984). These cases were largely based on a discovery that the government had intentionally and knowingly included tainted evidence in its case, including evidence created to cover up General John DeWitt's racial bias. See Peter Irons, Justice Delayed 206-12 (1989) (discussing the Japanese-American internment cases). Another, but decidedly less successful effort featured a class action lawsuit that attempted to compel the government to pay reparations to the internees beyond the small amounts Congress had already paid them. Hohri v. United States, 586 F. Supp. 769, 795 (D. D.C. 1984), rev'd in part by, 782 F.2d 227 (D.C. Cir. 1986), and vacated by, 482 U.S. 64 (1987).

Debate over the cases upholding the internment of Japanese-Americans still continues. In Adarand Constructors, Inc. v. Pena, 515 U.S. 200 (1995), the internment cases were discussed in the multiple opinions issued by the Court. Hirabayashi and Korematsu were cited in Justice Sandra Day O'Connor's majority opinion, $i d$. at 214-16, 224, 235, 236, in Justice John Paul Stevens's dissenting opinion, id. at 244 (Stevens, J., dissenting), and in Justice Ruth Bader Ginsburg's dissenting opinion, $i d$. at 275 (Ginsburg, J., dissenting). In all instances the Justices discussed the internment cases in a less than favorable manner. See id. at 215 (calling the internment cases "inexplicabl[e]"); id. at 236 (calling the racial classification behind the internment order "illegitimate"); id. at 244 n.2 (Stevens, J., dissenting) (calling the internment order "shameful"); id. at 275 (Ginsburg, J., dissenting) (calling the internment order an "odious, gravely injurious racial classification").

Chief Justice William H. Rehnquist, in his book on civil liberties during wartime, recognizes that modern opinion is very critical of the internment cases. WILLIAM H. REHNQUIST, ALL THE LAWS BUT ONE 203-11 (1998) (discussing the criticism of the government's detention of Japanese-Americans). Chief Justice Rehnquist believes that some of the criticisms of the internment order are not "well justified." Id. at 203. For instance, Chief Justice Rehnquist believes that the evacuation was not caused by racist suspicion by governmental leaders. Id. at 206. Judge Richard Posner of the United States Court of Appeals for the Seventh Circuit has offered a defense of Korematsu in his recent book on Bush $v$. Gore, 531 U.S. 98 (2000), asserting that the danger to the nation faced by Japanese-Americans was so great that the Court's decision was justified on pragmatic grounds. RICHARD A. POSNER, BREAKING THE DEADlock: THE 2000 Election, THE COURTS AND THE CONSTITUTION 171-73 (2001).

${ }^{157}$ There have been several cases dealing with the public policy aftermath of September 11 where courts have demonstrated a surprising degree of resistance to the efforts of the government. Detroit 
involves teaching law students, in their special citizenship role, about a case where courts stood up to political pressure and protected civil liberties. In order to give law students a sense about independent judicial behavior during wartime, we can examine Ex parte McCardle ${ }^{158}$ in conjunction with Ex parte Milligan, ${ }^{159}$ for instance, as well as other prominent instances of courts going against the political branches and preserving civil liberties during wartime. ${ }^{160}$

There is not enough time, however, to teach all of these cases. Therefore, Schneiderman has a better claim to be yoked with the cases that stand for judicial timidity. First, Schneiderman is an example of judicial independence during World War II, a war that many Americans think of as the leading member of the "canon" of heroic American idealism and selflessness. ${ }^{161}$ After all, to quote Tom Brokaw, the "greatest generation"

Free Press v. Ashcroft, 195 F. Supp. 2d 937, 946-48 (2002), aff'd by, 2002 FED App. 0291P (6th Cir.) (requiring the opening of an alien's removal proceeding); Hamdi v. Rumsfeld, 296 F.2d 278 (4th Cir. 2002) (requiring further discussion of need for enemy combatant to have access to counsel); Haddad v. Ashcroft, 2002 WL 31096692 (E.D. Mich. 2002) (requiring the government to release alien facing deportation or hold a new detention hearing that is open to the media and the general public); Center for Nat. Security Studies v. United States Dept. of Justice, 215 F. Supp. 2 d 94 (D.D.C. 2002) (requiring the release of the names of government detainees); North Jersey Media Group, Inc. v. Ashcroft, 205 F. Supp. 2d 288 (D. N.J. 2002) (allowing the press to have access to certain deportation hearings); Am. Civil Liberties Union v. County of Hudson, 799 A.2d 629 (N.J. Super. Ct. 2002) (requiring the release of information regarding certain government detainees). Even the case from the Ninth Circuit Court of Appeals invalidating parts of the Pledge of Allegiance can be seen as a bold judicial act, given that the Ninth Circuit was acting to invalidate one of the touchstones of the American civil religion during a time of increased patriotism. Newdow v. U.S. Congress, 292 F.3d 597 (9th Cir. 2002).

15874 U.S. 506 (7 Wall.) (1868).

15971 U.S. 2 (4 Wall.) (1866).

${ }^{160}$ New York Times Co. v. United States, 403 U.S. 713 (1971) (holding enjoinment of publication in the New York Times and Washington Post of classified information regarding Vietnam policy unjustified); Youngstown Sheet \& Tube Co. v. Sawyer, 343 U.S. 579 (1952) (holding President's Order to take possession of steel mills to avert a strike during the Korean War unconstitutional).

${ }^{161}$ Moreover, anyone familiar with that period of time in American history will know that, in practical terms, the Justices were not very independent from the ongoing American war. Thus it is very important to study a decision that demonstrates doctrinal and institutional independence. During this time, Justices Frank Murphy and Hugo Black followed the suggestion of President Franklin Delano Roosevelt and addressed audiences around the country on the need to support the war effort; Justice Murphy spoke to a Catholic audience about the Nazi threat to religious liberty, SIDNEY FINE, FRANK MURPHY: THE WASHINGTON YEARS 212 (1984), and Justice Black spoke to an audience in his home state of Alabama about the virtues of the war effort. ROGER NEwMAn, HUgo Black 313 (1994). Justice Black also went to Alabama to conduct an investigation of labor problems in the mines. Id. Justice Black had known General John Dewitt, whose order was under review in the internment cases, since 1930, and because their wives were such good friends the two of them socialized together quite a bit. Id. at 314 .

Justice Owen Roberts served as the head of a commission that investigated the attack on Pearl Harbor. FINE, supra, at 161. In the internment cases, the behind-the-scenes expertise and enthusiasm for the internment orders (to supplement General Dewitt's enthusiasm) came from Assistant Secretary of War John J. McCloy, a former student of Justice Felix Frankfurter's, whom Justice Frankfurter helped land his appointment and who kept Justice Frankfurter up-to-date on the war efforts. HOWARD Ball \& Philip CoOper, Of Power and Right: Hugo Black, William O. Douglas and AmerICA'S CONSTITUTIONAL REVOLUTION 115 (1992) ("Frankfurter was receiving information, especially 
fought that war. ${ }^{162}$ Furthermore, unlike other cases that may demonstrate judicial independence during World War II, ${ }^{163}$ or other times of war, ${ }^{164}$ Schneiderman had an enormous and immediate practical impact. ${ }^{165}$ Schneiderman prevented the potential denaturalization of hundreds of thousands of Americans. ${ }^{166}$

Finally, Schneiderman was by any measure an act of bold judicial independence, resisting executive wartime efforts in the middle of a war. True, at the time the case was filed the Soviets were potential enemies of America, and when the Court heard and decided the case the Soviets were American allies. Still, the Court-rather than issuing a discrete opinion during a time when Americans were rallying around their democratic principles as a source of national pride-came forward and said that communists were Americans. Furthermore, Schneiderman was issued by a Court that must have been aware that (given that Nazi Germany was an American enemy and that any American Nazi sympathizers might have possibly been perceived as dangerous and traitorous) it might soon hear a case involving the attempted denaturalization of a Nazi sympathizer. The Court would be forced to prevent that denaturalization, and find that a Nazi believed in the principles of the Constitution, because of its ruling in Schneiderman. One year later, the Court prevented the denaturalization of a proclaimed Nazi, citing Schneiderman as the grounds for its decision. ${ }^{167}$

Fundamentally, Schneiderman is a constitutional law case that certainly shaped the nature of American society after it was decided and thus should be considered part of the cultural literacy canon. ${ }^{168}$ In this way,

with respect to the Japanese exclusion cases involving the War Relocation Authority, on a weekly basis from John McCloy ....").

${ }^{162}$ TOM BroKAw, The GREATEST GENERATION (1998).

${ }^{163}$ The case discussed most often is probably West Virginia Board of Education v. Barnette, 319 U.S. 624 (1943), because it made a strong statement in favor of freedom. However, a relatively unknown case called United States v. Kuwabara, 56 F. Supp. 719 (1944), was also an act of substantial judicial independence in favor of civil liberties during wartime. In Kuwabara, the Judge stood up to government offers to prosecute disloyal individuals in internment camps who had been drafted and subsequently refused to serve.

${ }^{164}$ For instance, Ex parte Merryman, 17 F. Cas. 144 (C.C.D. Md. 1861) (No. 9,487) (holding that a military officer had "no right to arrest and detain a person not subject to the rules and articles of war, for an offense against the law of the United States" except under the aid and control of the judiciary), did not have the immediate practical consequences of Schneiderman.

${ }^{165}$ Infra notes 168-83 and accompanying text. The discussion should prove that Barnette, which simply allowed citizens the choice not to say the "Pledge of Allegiance," does not compare in practical importance to Schneiderman.

${ }^{166}$ Infra notes $175-76$ and accompanying text.

${ }^{167}$ Baumgartner v. United States, 322 U.S. 665, 677 (1944) (applying Schneiderman and holding there was insufficient evidence to cancel a certificate of citizenship).

${ }^{168}$ Balkin and Levinson briefly mention this "impact" branch of the cultural literacy canon. See Balkin \& Levinson, supra note 13, at 976 (arguing that the Dred Scott is a member of the cultural literacy canon because it "helped precipitate a civil war"). For political science literature on whether cases can really effectuate social change of any variety, see supra note 67. 
it has similarities in terms of practical import to Marbury v. Madison, ${ }^{169}$ McCulloch v. Maryland, ${ }^{170}$ Dred Scott v. Sandford ${ }^{171}$ Plessy v. Ferguson, ${ }^{172}$ Brown v. Board of Education, ${ }^{173}$ and Roe v. Wade. ${ }^{174}$ Schneiderman is a case from this group particularly worth studying now that immigration policy is of such national interest because it had an enormous practical impact in favor of immigrants. Schneiderman struck a decisive blow in favor of immigrants and immigrant rights, and, as I will discuss below, used constitutional law to radically change the composition of American society. Even before September 11, the practical impact of Schneiderman made it a case worth studying; however, given that its impact dealt with immigrants and immigration policy during wartime, a subject of great attention now, Schneiderman's practical impact has become of even greater interest. In the aftermath of September 11, when, by one count, approximately 725 immigrants are being detained and face possible deportation, ${ }^{175}$ it is extraordinarily important for law students and lawyers to be aware of the seminal case that protects immigrants and can lead an intelligent conversation about immigrant rights.

Had it not been for Schneiderman, it is possible that many naturalized American citizens would have lost their citizenship. As Justice Rutledge's concurrence noted, the Court's

[Schneiderman] decision affects millions. If, seventeen years after a federal court adjudged him entitled to be a citizen, that judgment can be nullified and he can be stripped of this most precious right, by nothing more than reexamination upon the merits of the very facts the judgment established, no naturalized person's citizenship is or can be secure. If this can be done after that length of time, it can be done after thirty or fifty years. If it can be done for Schneiderman, it can be done for thousands or tens of thousands of others. ${ }^{176}$

Given the stress that would continue to be imposed on the country dur-

${ }^{169} 5$ U.S. 137 (1 Cranch) (1803).

${ }^{170} 17$ U.S. 316 (4 Wheat.) (1819).

${ }^{171} 60$ U.S. 393 (19 How.) (1856).

172163 U.S. 537 (1896).

173347 U.S. 483 (1954).

${ }^{174} 410$ U.S. 113 (1973). Jerry Goldman's list of canonical cases—although his criteria for canonicity extends beyond practical impact-also includes Garcia v. San Antonio Metro Transit Auth., 469 U.S. 528 (1985); New York Times Co. v. United States, 403 U.S. 713 (1971) (The Pentagon Papers Case); Griswold v. Connecticut, 381 U.S. 479 (1965); Youngstown Sheet \& Tube Co. v. Sawyer, 343 U.S. 579 (1952); Lochner v. New York, 198 U.S. 45 (1905); and Gibbons v. Ogden, 22 U.S. 1 (9 Wheat.) (1824). Jerry Goldman, Is There a CANON of Constitutional LaW?, Am. Pol. Sci. Ass'n News. (Law and Courts Section of the Am. Political Science Ass'n), Spring 1993, at 3.

${ }^{175}$ Dan Eggen, Delays Cited in Charging Detainees: With Legal Latitude, INS Sometimes Took Weeks, WASH. POST, Jan 15, 2002, at A1.

${ }^{176} 320$ U.S. 118, 165-66 (1943) (Rutledge, J., concurring). 
ing World War II and later the Cold War, surely the United States government would have continued to pursue an aggressive denaturalization strategy for years to come-during such periods as the Cuban Missile Crisis, Vietnam, and during other periods where law enforcement authorities felt that there was a legitimate threat to national security ${ }^{177}$ — than it could have after Schneiderman. There were many Americans who had a lot to fear: The year that Schneiderman was naturalized, 200,000 certificates of naturalization were issued. ${ }^{178}$ Schneiderman made it very difficult for the United States Government to denaturalize citizens, ${ }^{179}$ and for years has been cited as the key case establishing that proposition. ${ }^{180}$ From this perspective, Schneiderman may be a welcome member of the critical legal theory impact canon, focusing attention on persecuted groups, as scholars like Jerome Culp have recently urged. ${ }^{181}$

If the Court had decided Schneiderman the other way, it would have been likely that millions more Americans would have been deported, ${ }^{182}$ and many more in the future might not have come to the United States, knowing how easily they could be deported for advocating "un-American" ideas. Even those in America who did not actually face potential denaturalization would have lived very different lives, lives full of more fear and panic than they already faced. Again consider Justice Rutledge's concurrence in Schneiderman:

No citizen with such a threat hanging over his head could be free. If he belonged to "off-color" organizations or held too radical or, perhaps, too reactionary views, for some segment of the judicial palate, when his admission took place, he could not open his mouth without fear his words would be held against him. For whatever he might say or whatever any such organization might advocate could be hauled forth at any time to show "continuity" of belief from the day of his admission, or "concealment" at that time . . . . His best course would be silence or hypocrisy. This is not citizenship. Nor is

${ }^{177}$ For a review of denationalizations by governments during World War I, see HANNAH ARENDT, THE ORIGINS OF TOTALITARIANISM 267-302 (2d ed. 1960).

${ }^{178} \mathrm{Id}$. at 177 (Stone, J., dissenting).

${ }^{179}$ This is because of the extremely high standard of proof required to denaturalize a citizen, a standard of proof that Schneiderman established. Supra note 48 and accompanying text.

${ }^{180}$ See supra note 12.

${ }^{181}$ E.g., Jerome M. Culp Jr., Autobiography and Legal Scholarship and Teaching: Finding the Me in the Legal Academy, 77 VA. L. REV. 539 (1991). This may be especially true because of the potential overtones for the critical race theorist of the fact that Schneiderman was a German Jew.

${ }^{182}$ As it stands, more than 1000 Americans lose their citizenship every year. According to the "Determination of Loss of U.S. Nationality Statistics" compiled by the U.S. State Department's Office of Citizens' Consular Services, 1,638 citizens lost their nationality during Fiscal Year 1977; 1,985 during Fiscal Year 1978; 1,236 during Fiscal Year 1979; 1,500 during Fiscal Year 1980; and 1,056 during Fiscal Year 1981. Had Schneiderman gone the other way, this number certainly would be much greater. 
it adjudication. ${ }^{183}$

This hidden-yet crucially important - saga in American constitutional history deserves mention, especially during a time when the government has once again started to round up thousands of citizens for deportation. Many of these citizens are naturalized. Before Schneiderman, the United States government would have been able to denaturalize citizens without clear justification and proof. However, Schneiderman held that as a quasiconstitutional matter naturalized citizens could have their citizenship stripped only with extraordinarily clear proof. Therefore, this case still matters today, because it will make it very hard for the United States government to pursue its desired post-September 11 strategy.

The culturally literate law student, educated in the ways of the law and constitutional development, must learn about Schneiderman because it can serve as a mechanism by which the student can be educated in the history of constitutional law and immigration regulation, an area of discussion that I will call the "immigration Constitution." This history is vitally important to understanding the constitutional history of this country, yet is missing from the American constitutional stock story. ${ }^{184}$ Consider the general conventional narrative of American constitutional development, reflected in Robert McCloskey's famous The American Supreme Court. ${ }^{185}$ American constitutional history is organized with three story-lines: The first organizing theme focuses on the national debate about federalism, a debate that began with the 1787 drafting of the Constitution, led to the Civil War, and lasted at least until Appomattox. ${ }^{186}$ With the triumph of the North in the Civil War, the traditional narrative then focuses on the constitutional implications of industrialization and economic change. ${ }^{187}$ These constitutional implications eventually manifested themselves in the New Deal and the battle in the Court over national power to regulate industry and labor. ${ }^{188}$ Next, the traditional narrative turns to the footnote four revolution. ${ }^{189}$ This narrative, obviously related to the immigration/national identity narrative, employs cases such as Dennis $v$. United States ${ }^{190}$ for discussions about the freedoms of native-born citizens, and not about the definition of the American national polity or the rights of non-native born citizens.

However, what the McCloskey narrative neglects - even as revised by

\footnotetext{
${ }^{183}$ Schneiderman, 320 U.S. 118, at 167 (1943) (Rutledge, J., concurring).

${ }^{184}$ For an interesting discussion of the role of stock stories, see Gerald P. Lopez, Lay Lawyering, 32 UCLA L. REV. 1, 5-9 (1984).

${ }^{185}$ Robert G. MCCloskey, The American Supreme Court (3d ed. rev. by Sanford Levison 2000).

${ }^{186} I d$. at $15,17-18,67-69$.

${ }^{187} \mathrm{Id}$. at $15,69-70$.

${ }^{188} I d$. at $15,108-09$.

${ }^{189} \mathrm{Id}$. at 15, 121-22. See also supra notes 71-80 and accompanying text.

${ }^{190} 341$ U.S. 494 (1951).
} 
Levinson, the sole scholar to pay a significant amount of attention to Schneiderman - is the epic story of American immigration history that pervades all of American constitutional history. Both racial and ideological pluralism play a central role in this narrative, but only in the context of the discussion of pluralism amongst those already and securely in the country. What about the regulations regarding which foreign nationals were let into the country, when and why they were allowed to stay, and what happened after these foreign nationals were let into the country? First, this is an extremely important element of understanding the current cultural makeup of American society. Second, examining these questions is important when evaluating constitutional protections-were these protections extended to the millions of recent immigrants? In answering this final question, understanding American constitutional development becomes as much about understanding the absence of constitutional activity as it does understanding its presence. ${ }^{191}$

Yet very little attention is paid to the constitutional law of immigration regulation. Most constitutional law casebooks discuss, at most, Plyler $v$. Doe,${ }^{192}$ while important constitutional law cases that have immigration law components do not discuss the immigration law issues posed by those cases. ${ }^{193}$ Subspecialties within constitutional law also ignore the importance of immigration law. Classic federal court cases on immigration law do not make their way into most federal court casebooks. ${ }^{194}$ While Schnei-

${ }^{191}$ Thus, Schneiderman and the focus on the "immigration Constitution" that can be fostered by studying this case in constitutional law classes can help debunk one common American stock story. Most prominently associated with Gunnar Myrdal and Louis Hartz, this story has minimized exclusion and difference. LOUIS HARTZ, THE LIBERAL TRADITION IN AMERICA: AN INTERPRETATION OF AMERICAN POLITICAL THOUght SINCE THE REVOLUTION (1955); GUNNAR MYRDAL, AN AMERICAN DILEMMA: THE NEGRO PROBLEM AND MODERN AMERICAN DEMOCRACY (1944). Historian Philip Gleason helpfully summarized this stock story, writing that to be an American:

[A] person did not have to be of any particular national, linguistic, religious, or ethnic background. All he had to do was to commit himself to the political ideology centered on the abstract ideals of liberty, equality, and republicanism. Thus the universalist ideological character of American nationality meant that it was open to anyone who willed to become an American.

Philip Gleason, American Identity and Americanization, in CONCEPTS OF ETHNICITY 62 (William Petersen et al. eds., 1982) (1980). The discussion below demonstrates the impact that immigration regulation has had on American constitutional development.

${ }^{192} 457$ U.S. 202 (1982) (holding states may not discriminate against aliens in certain areas of education policy).

${ }^{193}$ See INS v. Chadha, 462 U.S. 919 (1983) (holding the legislation veto provision found in 8 U.S.C. $\$ 1254(\mathrm{c})(2)$, which was part of the immigration statute's suspension-of-deportation section, is unconstitutional).

${ }^{194}$ Besides Schneiderman, the other landmark Supreme Court cases are generally considered to be: Baumgartner v. United States, 322 U.S. 665 (1944); Tutun v. United States, 270 U.S. 568 (1926); Ng Fung Ho v. White, 259 U.S. 276 (1922); United States v. Ju Toy, 198 U.S. 253 (1905); and Wong Wing v. United States, 163 U.S. 228 (1896). In the first edition of the most famous federal courts casebook, these cases were all included or discussed. See HENRY M. HART \& HERBERT WeSChLER, The Federal Courts and the Federal System 105, 328-30, 1390-91 (1953). The Fourth Edition of this casebook, edited by several law professors, still contains Tutun, and mentioned $\mathrm{Ng}$ Fung Ho, but no 
derman is not a complete overview of the centrality of immigration regulation in American constitutional history, it certainly provides a nice starting point. Schneiderman discusses in its various opinions the long history of immigration regulations that have limited who can become an American, how long they can stay an American, and what constitutional protections apply to them while they are in the United States. Schneiderman is a helpful way of focusing on the "immigration Constitution" because of its own importance in immigration legal history.

Students of immigration policy have usually advanced one of two incorrect versions of the history of American immigration policy. First, some differentiate between long periods of "liberal" eras of immigration policy, followed by long periods of "racist" immigration policy. ${ }^{195}$ Second, some have adopted a more institutional approach and have differentiated between a long period without immigration regulation, starting in the early Republic and extending to $1882,{ }^{196}$ and the period starting after 1882 which saw the emergence of immigration regulation. ${ }^{197}$ However, Gerald L. Neumann has demonstrated that control over immigration has always existed, and thus has always formed a central part of the American constitutional narrative for the reasons discussed above. ${ }^{198}$

Before and immediately after the Revolutionary War, states all over the country limited those who could live in their state. In 1787, for instance, Georgia passed a statute requiring that aliens transported or banished from

other immigration law cases. RichARD H. FALLON, JR. ET AL., HART \& WECHSLER'S THE FEDERAL COURTS AND THE Federal SySTEM 107-10, 397 (4th ed. 1996). However, of the other current casebooks, only one mentions $\mathrm{Ng}$ Fung Ho, DAVID P. CURRIE, FedERAL COURTS 144 n.3 (3d ed. 1982), while the other casebooks fail to mention any of the immigration cases. See PeTER W. Low \& John C.

JefFries, JR., Federal CourTs AND the LAW of FedERAL-STAte Relations xlvii-lvii (3d ed. 1994), or ChARLES T. MCCORMiCK ET AL., Federal COURTS xv-xxi (9th ed. 1992).

${ }^{195}$ For books discussing immigration policies and race, see LAWRENCE H. FUCHS, THE AMERICAN Kaleidoscope: Race, Ethnicity and the Civic Culture (1990), and Daniel J. Tichenor, Regu-

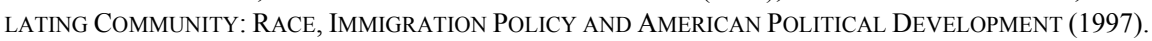

${ }^{196}$ In 1882, federal control of immigration began when the Secretary of Treasury was authorized to regulate immigration. Act of Aug. 3 1882, ch. 376, 22 Stat. 214 (1882).

${ }^{197}$ The myth that there was unrestricted immigration for a long time is widely shared. See, e.g., Kleindienst v. Mandel, 408 U.S. 753, 761 (1972) (stating that "[u]ntil 1875 alien migration to the United States was unrestricted"); see also 1 CHARLES GoRDON \& STANLEY MAILMAN, IMMIGRATION LAW AND PROCEDURE 2-5 (rev. ed. 1993) (discussing that "[t]he first one hundred years of our national existence was a period of unimpeded immigration" in which "[t]he gates were open and unguarded and all were free to come"); Peter H. SChUCK \& Rogers M. SMith, Citizenship Without Consent: ILLEGAl ALIENS IN THE AMERICAN POLITY 92 (1985) (stating that until 1876 "[t]he nation maintained a policy of completely open borders").

${ }^{198}$ Gerald L. NEUman, Strangers to the CONSTITUtion: ImMigrants, Borders AND FunDAMENTAL LAW 19-43 (1996) (discussing the open borders myth); see also Gibbons v. Ogden, 22 U.S. 1,203 (1824) (stating that "quarantine laws [and] health laws of every description" formed part of the "immense mass of legislation, which embraces everything within the territory of a State, not surrendered to the general government"). 
another state or foreign country were not allowed to enter the state. ${ }^{199}$ Simultaneously, the Congress of the Confederation passed a resolution in late 1788 recommending that the states should "pass proper laws for preventing the transportation of convicted male-factors from foreign countries into the United States." ${ }^{200}$ States responded to this call for action. ${ }^{201}$ Around the same time, some states passed laws imposing criminal penalties on anyone who brought an indigent person into the state. ${ }^{202}$

Many years after the Revolution, yet prior to the Civil War, many supposedly free states passed laws forbidding blacks from moving to their states. ${ }^{203}$ These prohibitions were sometimes pursuant to the command of a state constitution. $^{204}$ Slave states usually barred the entry of free blacks who were not already residents of their particular states. ${ }^{205}$ Over time these slave states eventually extended this prohibition on entry to their own free black residents who sought to return to their home state after traveling to

${ }^{199}$ Act of Feb. 10, 1787, 1787 Ga. Acts 40.

${ }^{200} 13$ J. OF CONG. 105-06 (Sept. 16, 1788) ("Resolved, that it be, and it is hereby recommended to the several states to pass proper laws for preventing the transportation of convicted malefactors from foreign countries into the United States.").

${ }^{201}$ Connecticut passed a law banning the introduction of convicts sentenced to transportation by a foreign country. Act of Oct. 1788, 1788 CONN. ACTS \& LAws 367; For examples of statutes of Massachusetts, Pennsylvania, South Carolina, and Virginia that forbade the admittance of persons who had been convicted of a crime of any sort, see Act of Feb. 14, 1789, ch. 61, § 7, 1789 Mass. Acts 98, 10001; Act of Mar. 27, 1789, ch. 463, 1788-89 Pa. Acts 692; Act of Nov. 4, 1788, No. 1542, 1788 S.C. Acts 5; Act of Nov. 13, 1788, ch. 12, 1788 Va. Acts 9. These states were later followed by Maine, Maryland, New Jersey, New York, and Rhode Island. Act of Feb. 24, 1821, ch. 22, § 6, 1821 Me. Laws 90, 91- 92; Act of Jan. 6, 1810, ch. 138, § 7(3), 1809-10 Md. Laws; N.J. Act of Jan. 28, 1797, ch. 611, 1797 N.J. Laws 266; Act of Apr. 25, 1833, ch. 230, 1833 N.Y. Laws 313; R.I. Act of 1798, § 16.

${ }^{202}$ Act of Feb. 26, 1794, ch. 32, § 15, 1794 Mass Acts \& Laws 375, 379, 383; N.Y. Act of Mar. 7, 1788 , ch. $62, \S 33$.

${ }^{203}$ Act of Feb. 12, 1853, § 3, 1853 Ill. Gen. Laws 354, 354; Act of June 18, 1852, ch. 74, § 1, 1852 Ind. Rev. Stat. 375, 375; Act of Feb. 5, 1851, ch. 72, § 1, 1850-51 Iowa Acts 172, 172.

${ }^{204}$ E.g., ILL. CONST. of 1848, art. XIV ("The general assembly shall, at its first session under the amended constitution, pass such laws as will effectually prohibit free persons of color from immigrating to and settling in this state; and to effectually prevent the owners of slaves from bringing them into this state, for the purpose of setting them free."); IND. CONST. OF 1851, art. XIII, § 1 ("No Negro or mulatto shall come into, or settle in, the State, after the adoption of this Constitution."); IND. CONST. OF 1851, art. XIII, § 2 ("[A]ny person who shall employ such Negro or Mulatto, or otherwise encourage him to remain in the State, shall be fined in any sum not less than ten dollars, nor more than five hundred dollars.").

${ }^{205}$ ALA. CoDE pt. 1, tit. 13, ch.4, art. 2, §§ 1033, 1034 (1852); Act of Jan. 20, 1843, § 2, 1843 Ark. Acts 61, 61; Act of Jan. 28, 1811, ch. 146, § 1, 1811 Del. Laws 400, 400; Act of Dec. 19, 1818, No. 512, § 3, 1818 Ga Acts 126, 127; MIss. CoDE ch. 37, art. 2, § 80 (1848) (enacted June 18, 1822); Act of Feb. 12, 1827, ch. 21, 1826-27 N.C. Acts 13; see also KY. CONST. OF 1850, art. X, § 2 ("The General Assembly shall pass laws providing that any free negro or mulatto hereafter immigrating to, and any slave hereafter emancipated in, and refusing to leave this State, or having left, shall return and settle within this State [sic], shall be deemed guilty of felony, and punished by confinement in the penitentiary thereof."). 
another country. ${ }^{206}$

In the aftermath of the Civil War, Asians began to face restrictive immigration laws, on the naturalization front by the Nationality Act of 1870 and on the immigration front by the Chinese Exclusion Act of May 6, 1882. ${ }^{207}$ Later, on August 3, 1882, Congress passed a law that imposed a head tax of fifty cents on each immigrant and forbade the entrance of idiots, lunatics, convicts, and persons likely to become public charges. ${ }^{208}$ Several years later, beginning in 1891, polygamists, persons convicted of crimes involving "moral turpitude," and anyone suffering from a contagious disease was not allowed to enter the United States. ${ }^{209}$

The start of the twentieth century featured a host of new laws expanding the scope of who could be excluded from entry into the country. Beginning in 1903, epileptics, insane persons, professional beggars, and anarchists could not be admitted to the country. ${ }^{210}$ In 1917, Congress required that any potential immigrant pass a literacy test before they could be admitted into the country. ${ }^{211}$ In 1924, responding to the rapid rise in immigration rates that increased the numbers of Americans from Eastern and Southern Europe ${ }^{212}$ Congress created a "national origins" quota system. ${ }^{213}$ Each country was allotted a specific number of allowable immigrants, fixed in proportion to the national origin of the total U.S. population, by birth or descent, reported in the 1920 census. ${ }^{214}$

There were also ideological immigration limitations. Many states did not allow Loyalists to enter their state. ${ }^{215}$ The first federal naturalization law simply required an oath to support the U.S. Constitution. ${ }^{216}$ The second naturalization statute, passed by Congress in 1795, added two more clear ideological components: The renunciation of titles or orders of nobility and the requirement that the naturalizing court find that the applicant has "behaved as a man ... attached to the principles of the Constitution of

${ }^{206}$ Del. Act of Jan. 28, 1811, ch. 146, § 4 (traveling outside state for six months); Act of Dec. 26, 1835, § 3, $1835 \mathrm{Ga}$. Acts 265, 266 (unless traveling to “an adjoining State"); Act of 1830-31, ch. 14, 1830-31 N.C. Acts 16 (traveling outside state for 90 days). In addition, the Chinese were generally barred from entry to the United States as a result of the federal Chinese Exclusion Act. Act of May 6, 1882, ch. 126, 22 Stat. 58 (prohibiting Chinese laborers from entering the country on the basis that they endanger certain localities within the territory).

${ }^{207}$ Act of July 14, 1870, ch. 254, 16 Stat. 254 (1870); $§ 1,22$ Stat. at 58-59.

${ }^{208}$ Act of Aug. 3, 1882, ch. 376, §§ 1-4, 22 Stat. 214, 214-15 (repealed 1967).

${ }^{209}$ Act of Mar. 3, 1891, ch. 551, § 1, 26 Stat. 1084.

${ }^{210}$ Act of Mar. 3, 1903, ch. 1012, § 2, 32 Stat. 1213.

${ }^{211}$ Immigration Act of 1917, ch. 29, § 3, 39 Stat. 874, 877 (repealed 1952).

${ }^{212}$ United States DePartment of Justice, 1997 Statistical YEARBOOK OF THE IMMigRaTION AND NATURALIZATION SERVICE 15 chart B, 24-25 tbl. 2 (1999).

${ }^{213}$ See Immigration Act of 1924, ch. 190, 43 Stat. 153, 153-159.

${ }^{214} \mathrm{Id}$. The legislation also barred all immigration from China. Id. at 168.

${ }^{215}$ E.g., Act of Nov. 16, 1792, ch. 62, § 2, 1792 Va. Acts 65, 65 (declaring it "lawful for the governor ... [to] compel[] to depart this Commonwealth, all suspicious person" from foreign powers from whom the President "shall apprehend hostile designs" against the United States).

${ }^{216}$ Act of Mar. 26, 1790, ch. 3, 1 Stat. at 103. 
the United States. ${ }^{, 217}$ Indeed, the Alien and Sedition Acts, most known for their role in the constitutional history of freedom of speech, ${ }^{218}$ were really a package of three statutes that included provisions aimed directly at aliensthe Naturalization Act of $1798,{ }^{219}$ the Alien Enemies Act, ${ }^{220}$ and the Alien (or Alien Friends) Act. ${ }^{221}$ The Alien Act, for instance, allowed the President of the United States - without any limitation or constraint whatsoever- to arrest and deport any alien he so desired. ${ }^{222}$

The 1906 Naturalization Act precluded polygamists or those who believed in political assassination from becoming citizens. ${ }^{223}$ A 1940 congressional statute expanded those included in disfavored groups to include those who believed in the overthrow of the U.S. government or were affiliated with organizations advocating these proscribed ideas. ${ }^{224}$ A 1950 federal statute added the even more specific designation of support of the Communist Party and the "economic, international and governmental doctrines of world communism" as bases for exclusion, deportation, and disqualification from naturalization. ${ }^{225}$ The 1990 Immigration Act eliminated a number of the ideological prerequisites for naturalization. ${ }^{226}$ Still, current federal law does bar individuals who hold certain beliefs from becoming

${ }^{217}$ Act of Jan. 29, 1795, ch. 20, s 1, 1 Stat. 414; see JAMES H. KeTtNER, THE Development OF AMERICAN CITIZENSHIP, 1608-1870, at 239-43 (1978). The language used in this statute- "attached to the principles of the Constitution of the United States" - was included after the earlier phrase "attached to a 'Republican' form of government" met with the disapproval of some members of Congress who felt that the old, replaced phrase was not as clear as the new phrase. 1 ANNALS OF CONG. 1021-23 (Joseph Gales ed., 1795). James Madison, however, expressed the opinion that Republican "was well enough understood to signify a free Representative Government, deriving its authority from the people, and calculated for their benefit ...." Id. at 1022. This debate about the meaning of the phrase "Republican form of government" has trickled over into contemporary American constitutional scholarship, as represented most notably by an excellent symposium held at the University of Colorado School of Law. 65 U. COLO. L. REV. 709 (1994).

${ }^{218}$ E.g., John C. Miller, CRisis In Freedom: The Alien AND SEdition ACts (1951); JAMES Morton SMith, THE AliEn AND SEDITION LAwS AND AMERICAN CIVIL LiBERTIES (1956).

${ }^{219}$ Act of June 18, 1798, ch. 54, 1 Stat. 566.

${ }^{220}$ Act of July 6, 1798, ch. 66, 1 Stat. 577.

${ }^{221}$ Act of June 25, 1798, ch. 58, 1 Stat. 570. The Sedition Act, ch. 74, 1 Stat. 596, was a criminal statute equally regulating the speech of citizens and aliens, and not a regulation of migration.

${ }^{222}$ Alien Act $\S 1$.

${ }^{223}$ Act of June 29, 1906, ch. 3592, §§ 4, 7, 34 Stat. 596, 597, 599.

${ }^{224}$ Nationality Act of 1940, ch. 876, § 305, 54 Stat. 1137, 1141 (1940). Aliens who believed in such ideas or were affiliated with such organizations had already been made excludable and deportable from the United States. Act of October 16, 1918, ch. 186, 40 Stat.1012 (providing for deportation on ideological grounds); Act of February 5, 1917, ch. 29, § 3, 39 Stat. 874, 875 -78 (providing for exclusion on ideological grounds).

${ }^{225}$ Internal Security Act of 1950 , ch. 1024, $\S \S 22,25,64$ Stat. 987, 1006-10, 1013-15.

${ }^{226}$ Compare 8 U.S.C. $\S 1182(a)(3)(D)$ (exclusion on grounds of membership in totalitarian party, rewritten in 1990) and 1251(a)(4) (1994) (deportation grounds rewritten in 1990 to omit deportation for party membership) with the Immigration and Nationality Act, ch. 477, $\S \S 212(\mathrm{a})(28)$ (exclusion for party membership or advocacy) and $\S 241(a)(6)$ (deportation for party membership or advocacy), 66 Stat. 163, 184-86, 205-06. 
Americans. ${ }^{227}$

These laws have substantially altered the composition of the American population both in terms of ethnicity as well as ideology. Furthermore, these laws can also tell us a lot about the extent of the constitutional protections for the millions of immigrants and less fortunate who wanted to, and sometimes did, make it to American shores.

Schneiderman analyzes many of these regulations and discusses the impact of limiting who can come and who can stay in the United States, had on American constitutional development. This history of immigration regulation had obvious ramifications on the ethnic and ideological content of the American polity. The United States has managed to stay very "white" and relatively homogeneous in terms of ideology due at least in substantial part to these regulations. Many commentators, for instance, have noted the difference between the way American immigration policy has treated Cubans and the way American immigration policy has treated Haitians. ${ }^{228}$ Illegal immigrants caught entering the United States are often immediately returned to their home countries. ${ }^{229}$ However, since the 1966 Cuban Readjustment Act, all Cubans who reach American soil are allowed to stay in the United States. ${ }^{230}$ Thus, Cubans, who are white, are granted citizenship, while black Haitians are almost always repatriated. If more Haitians and/or fewer Cubans had been admitted to the country (leaving aside whether this change in policy would be a good idea or not), the ethnic composition of the United States would obviously be substantially different.

With respect to constitutional law, the history of immigration regulation has several consequences for American constitutional doctrine and the American constitutional narrative. It sheds doubt on any American narrative that focuses on the embrace of diversity in American history, ethnicity

${ }^{227}$ Federal law bars those who advocate or are affiliated with an organization that advocates opposition to all organized government from becoming Americans. 8 U.S.C. $\S 1424(a)(1)(2000)$. Individuals affiliated with the Communist Party of any nation-state - including the United States - cannot become Americans, nor can individuals who are at all affiliated with any totalitarian parties. 8 U.S.C. $\S$ 1424(a)(2) (Supp. V 1993). Moreover, individuals who advocate the overthrow by force of the U.S. government or its officials, or who write in favor of or belong to any organization that supports such ideas, cannot be naturalized. Id. $\S \S 5-6$.

${ }^{228}$ E.g., Noah Isackson, Immigration Inequity Cited: Cubans Welcome, Haitians In Limbo, Jackson Says, CHI. TrIB., Apr. 26, 2000, at 3, LEXIS, News Library, Chtrib File; Christine Evans, Why The World Doesn't Know About Sophonie, PAlm BEACH Post, Apr. 23, 2000, at 1A, LEXIS, News Library, Pbpst File. See generally Malissia Lennox, Note, Refugees, Racism, and Reparations: A Critique of the United States' Haitian Immigration Policy, 45 STAN. L. REV. 687 (1993) (analyzing the discriminatory and disparate treatment of Haitian immigrants under U.S. immigration and naturalization policies).

${ }^{229}$ Haitians Hit U.S. Policy as Unfair, CHIC. TRIB., Jan 16, 2000, at C9, LEXIS, News Library, Chtrib File.

${ }^{230}$ Cuban Refugees: Adjustment of Status, Pub. L. 89-732, 80 Stat 1161 (1966) (amended by Pub. L. No. 94-571, 90 Stat. 2706 (1976) \& Pub. L. No. 96-212, § 203(I), 94 Stat. 108 (1980)). Codified as amended in 8 U.S.C. $\S 1255$. 
or ideology. ${ }^{231}$ Even in the early years of this nation, when the First Amendment was adopted, the United States did not welcome individuals with disfavored political ideals. This significantly affected the ideological composition of the American population. As previously discussed, there is also a long history of ethnic and racial limitations on who could become a citizen. From 1790 until 1952, federal law stipulated that a person basically had to be considered "white" in order to be eligible for American citizenship. ${ }^{232}$ Were it not for the Chinese Exclusion Act of $1892^{233}$ and the Immigration Act of $1924,{ }^{234}$ for instance, many more Asian Americans would live in the United States today. ${ }^{235}$ These regulations explain why eighty-five percent of the American population in 1900 was white, and why it is projected that it will be about fifty percent non-white by the year $2050 .{ }^{236}$ This projected demographic figure might have been the reality in 1850, but for immigration regulation. Certainly, with a different American population, American constitutional doctrine would be different. If there had been a different American people, then surely fundamental rights jurisprudence, for instance, would be very different, because the rights "rooted in the traditions and conscience of our people" 237 would be different.

Consider also the second version of the "immigration Constitution" notion that Schneiderman impacts. Given the large numbers of immigrants in the United States, ${ }^{238}$ the application of constitutional rules to immigrants would generally be important regardless of how strongly or weakly these rules were applied against them. Given how weakly these rules have been applied to immigrants, any constitutional narrative must discuss immigration because of the glaring absence of constitutional action in that area. Irrespective of how many immigrants have failed or succeeded in immigrating to the United States, the long and unfortunate history of American discrimination in immigration policy should be a central part of any discussion on American history of liberalism. Schneiderman is the perfect case

231 Thus rejecting the Hartz narrative mentioned supra note 191.

${ }^{232}$ The restriction was included in the very statute passed by the United States with respect to naturalization. Act of Mar. 26, 1790, ch. 3, 1 Stat. 103.

${ }^{233}$ Act of May 6, 1882 (Chinese Exclusion Act of 1882), ch. 126, 22 Stat. 58 (repealed by Act of Dec. 17, 1943, ch. 344, 57 Stat. 600).

${ }^{234}$ Immigration Act of 1924, ch. 190, 43 Stat. 153 (repealed by Immigration and Nationality Act of 1952, (McCarran-Walter) ch. 477, tit. IV, § 403(a)(23), 66 Stat. 163, 279).

${ }^{235}$ Bill Ong Hing, Making And Remaking Asian America Through ImMigration Policy 1850-1990 at 43-49 (1993) (discussing immigration from Asia prior to 1965).

${ }^{236}$ Supra notes 143-44 and accompanying text.

${ }^{237}$ Palko v. Connecticut, 302 U.S. 319, 325 (1937) (emphasis added).

${ }^{238}$ At least 48 million immigrants reached the United States between 1821 and 1978. STAFF REPORT OF THE SELECT COMM'N ON IMMigRation AND REFugEe Policy, U.S. IMMigRation Policy AND THE NATIONAL INTEREST 172 (1981); see also Percentage of Foreigners in U.S. Rises Sharply, N.Y. TIMES, Dec. 20, 1992, § 1 at 36. 
to illustrate this and to discuss the "immigration Constitution." Schneiderman is a significant case, both doctrinally and practically, for assessing the Constitution's application to immigration.

In addition to expanding the general constitutional stock story, ${ }^{239}$ Schneiderman focuses attention on the discussion of several specific areas such as the newly relevant constitutional protection of immigrants. First, the Constitution devotes a significant amount of attention to procedural protections for individuals. Any history of the constitutional protection of liberties under the Fifth ${ }^{240}$ or Fourteenth Amendment ${ }^{241}$ must take into account the way constitutional law has regulated liberty of immigrants. Citizenship is one of the most fundamental of our liberties ${ }^{242}$ and millions of Americans are only naturalized citizens as opposed to native citizens, whose crucial citizenship status depends on the protection of Schneiderman. As Schneiderman itself recognized:

In its consequences it is more serious than a taking of one's property, or the imposition of a fine or other penalty. For it is safe to assert that nowhere in the world today is the right of citizenship of greater worth to an individual than it is in this country. It would be difficult to exaggerate its value and importance. By many it is regarded as the highest hope of civilized men. This does not mean that once granted to an alien, citizenship cannot be revoked or cancelled on legal grounds under appropriate proof. But such a right once conferred should not be taken away without the clearest sort of justification and proof. So whatever may be the rule in a naturalization proceeding . . . in an action instituted . . . for the purpose of depriving one of the precious right of citizenship previously conferred we believe the facts and the law should be construed as far as is reasonably possible in favor of the citizen. ${ }^{243}$

\footnotetext{
${ }^{239}$ Supra notes 184,194 and accompanying text.

${ }^{240}$ U.S. CONST. amend. V ("No person shall . . . be deprived of life, liberty, or property, without due process of law.").

${ }^{241}$ U.S. CONST. amend. XIV $\S 1$ ("No State shall . . . deprive any person of life, liberty, or property, without due process of law."). I mention this provision and its protection of liberty because, as discussed supra notes 201-224 and accompanying text, many state regulations have affected citizenship rights, even beyond the more prominent and famous federal regulations.

${ }^{242}$ This is yet another reason for making Schneiderman part of the cultural literacy canon. If citizenship is a fundamental aspect of human existence, then tracing its history (and therefore studying the key case discussing citizenship) is a subject that every culturally literate lawyer should have studied.

${ }^{243} 320$ U.S. 118, 122; see also Trop v. Dulles, 356 U.S. 86, 101 (1958) (holding that the deprivation of citizenship "is a form of punishment more primitive than torture, for it destroys for the individual the political existence that was centuries in the development"); Perez v. Bronwell, 356 U.S. 44, 64 (1958) (Warren, C.J., dissenting) (describing citizenship as "man's basic right for it is nothing less than the right to have rights" and arguing that to "[r]emove this priceless possession and there remains a
} 
Schneiderman provides a helpful means of talking about the procedural history of regulating citizenship because the case discusses this history in great detail, and is an important case doctrinally. Yet Schneiderman and its progeny, such as Baumgartner v. United States ${ }^{244}$ and Chaunt v. United States ${ }^{245}$ do not appear anywhere in any substantial way in constitutional law casebooks.

Second, consider the general notion of equality. It is important to teach slavery because of its centrality to Americans' awareness of the presence of chattel slavery in our background as a core part of the American constitutional experience with equality. ${ }^{248}$ It is likewise important to look at immigration in terms of how to protect potential and actual immigrants and newly arrived Americans from discrimination. Granted, discriminatory rules in immigration law have involved differing classifications, from ideological to ethnic classifications. Any narrative about discrimination, however, must consider the history of discrimination in determining who could come to the United States and what would happen to immigrants after they arrived here. These subjects are both discussed in Schneiderman and significantly affected by Schneiderman.

What does it say for the traditional constitutional narrative if courts

stateless person, disgraced and degraded in the eyes of his countrymen. He has no lawful claim to protection from any nation, and no nation may assert rights on his behalf. His very existence is at the sufferance of the state within whose borders he happens to be"). See Michael Walzer, SPHERES of Justice: A DEFENSE OF PluRALISM AND EQUALiTy 31-35 (1983) (arguing that citizenship implicates the single most important question in distributive justice: Who constitutes the relevant community and how is this community itself constituted?).

${ }^{244} 322$ U.S. 665 (1944). In Baumgartner, the government attempted to set aside a naturalization decree because of the new citizen's support for Nazi principles (rather than the Communist principles that Schneiderman supported). Id. Applying the Schneiderman standard of clear, unequivocal, and convincing proof, the Court decided that there was not that "solidity of proof which leaves no troubling doubt in deciding a question of such gravity as is implied in an attempt to reduce a person to the status of alien from that of citizen." Id. at 670. Justice Murphy, writing for the majority, went on to write that American citizenship is not a right granted on a condition subsequent that the naturalized citizen refrain in the future from uttering any remark or adopting an attitude favorable to his original homeland or those there in power, no matter how distasteful such conduct may be to most of us .... The naturalized citizen has as much right as the natural-born citizen to exercise the cherished freedoms of speech, press, and religion, and without "clear, unequivocal, and convincing" proof that he did not bear or swear true allegiance to the United States at the time of naturalization he cannot be denaturalized.

Id. at $679-80$.

${ }^{245} 364$ U.S. 350, 351 (1960) (another Communist denaturalization case).

${ }^{248}$ Sanford Levinson, Slavery in the Canon of Constitutional Law, 68 CHI.-KENT. L. REv. 1087, 1094-95 (1993). 
have long acknowledged that the government can classify non-native born Americans in potentially troublesome ways ${ }^{249}$ In the early twentieth century alone, cases upheld against constitutional attack state laws forbidding aliens from owning land, ${ }^{250}$ laws barring aliens from benefiting from public construction contracts, ${ }^{251}$ and laws allowing only citizens the privilege of harvesting wildlife. ${ }^{252}$ The Supreme Court also intervened and invalidated a statute that limited the abilities of noncitizens to be employed in the private sector, ${ }^{253}$ and it also reaffirmed that anything "public," like public employment or public benefits, could be distributed by the government only to citizens, if the government so desired. ${ }^{254}$ Moreover, as discussed earlier, ${ }^{255}$ there is a long history of limiting which races could enter the country. This history has had a large impact on the racial composition of the American population and is important in evaluating the constitutional history of race relations because these laws have affected the lives of millions of minority Americans.

This notion of the "immigration Constitution" has even greater salience after September 11, because both elements of this notion are implicated by the government's response to the events of that day. The government has focused a good deal of its attention on what David Cole has called "enemy aliens," $" 256$ enacting a number of programs that have dramatic implications for the immigration Constitution. First of all, consider the first prong of the notion of the immigration Constitution, regarding who can enter the country and what effect that has on American constitutional law. The USA Patriot Act bars admission to the United States of aliens who "endorse or espouse terrorist activity" or who "persuade others to support terrorist activity or a terrorist organization." 257

Second, consider the second prong of the notion of the immigration Constitution, regarding the extent of constitutional protections that individuals not born in the United States enjoy. In the post-September 11th world, the government has significantly limited the rights of non-native born individuals, and any culturally literate law student and lawyer must be able to discuss these. Law students and lawyers must be able to discuss a case that had a significant impact on the constitutional rights enjoyed by

${ }^{249}$ Mathews, 426 U.S. at 80.

${ }^{250}$ Frick v. Webb, 263 U.S. 326, 333-34 (1923).

${ }^{251}$ Crane v. New York, 239 U.S. 195, 197-98 (1915).

${ }^{252}$ Patsone v. Pennsylvania, 232 U.S. 138, 143, 145-46 (1914).

${ }^{253}$ Traux v. Raich, 239 U.S. 33, 39, 43 (1915).

${ }^{254}$ Id. at $39-40$.

${ }^{255}$ Supra notes 201-24 and accompanying text.

${ }^{256}$ David Cole, Enemy Aliens, 54 StAN. L. REV. 953, 989-94 (2002)

${ }^{257}$ Uniting and Strengthening America by Providing Appropriate Tools Required to Intercept and Obstruct Terrorism (USA PATRIOT) Act of 2001, Pub. L. No. 107-56, 115 Stat. 272, 346 (2001) (codified as amended at 8 U.S.C. $\$ 1182(a)(3)(2002)$ ) [hereinafter USA PATRIOT Act]; see also Cole, supra note 256, at 966-69 (discussing this passage of the USA PATRIOT Act). 
non-native born Americans, a case such as Schneiderman. The USA Patriot Act, for instance, dramatically altered the rules governing detention of immigrants. Before the passage of the Patriot Act, aliens in removal proceedings could be subject to preventative detention only in the same situations under which a regular defendant could be subject to preventative detention in a criminal proceeding: They could be detained without bond if it was determined that they posed a major risk to the community or a risk of flights. ${ }^{258}$ The USA Patriot Act, however, allows the Attorney General to detain aliens without a hearing and without proof that the alien poses a national security or flight risk. ${ }^{259}$

The government has also closed all hearings for immigration detainees to the public, the press, and even family members, on orders from Attorney General John Ashcroft and Chief Immigration Judge Michael Creppy. ${ }^{260}$ The government has also refused to even release the names of those in detention until it was (in part) ordered to do so by a judge. ${ }^{261}$ My aim is not to take a position regarding any of these post-September 11 measures, but simply to point out that these measures are in place. These measures implicate the immigration Constitution, and thus the contextualization of the canon means that Schneiderman is even more relevant today.

There are certainly other cases involving immigration (and particularly naturalization) that have had substantial practical import. Most notably, in Afroyim v. Rusk, ${ }^{262}$ the Court held that citizenship could only be renounced

${ }^{258}$ O’Rourke v. Warden, 539 F. Supp, 1131, 1135 (S.D.N.Y. 1982). The court found that: [t]he [Bureau of Immigration Affairs] has construed [the statute] to provide that the determination to release an alien pending deportation proceedings is 'not a discretionary form or relief' but rather 'an alien should be detained or required to post a bond, only if he is a threat to national security or is a poor bail risk.'

Id. (citing In re Patel, 15 I. \& N. Dec. 666 (B.I.A. 1976)). See also In re Drysdale, 20 I \& N Dec. 815, 817 (BIA 1994) ("Once it is determined that an alien does not present a danger to the community or any bail risk, then no bond should be required."); In re De La Cruz, 20 I \& N Dec. 346, 349 (B.I.A 1991) ("[A]n alien, whom the Service in its discretion has arrested and taken into custody, generally should not be detained or required to post bond pending a determination of deportability except on a finding that he is a threat to the national security or is a poor bail risk.").

${ }^{259}$ USA PATRIOT Act, Pub. L. No 107-56, 115 Stat. 351 (codified as amended at 8 U.S.C. § 1226a (2001))

${ }^{260}$ Memorandum from Chief Immigration Judge Michael Creppy to all Immigration Judges (Sept. 21,2001 ) (on file with the Connecticut Law Review).

${ }^{261}$ Ctr. For Nat'l Sec. Studies v. United States Dep't of Justice, 2002 U.S. Dist LEXIS 14168 (D.C. Cir.), stay granted by 2002 U.S. Dist. LEXIS 125020; see also Detroit Free Press v. Ashcroft, 195 F. Supp. 2d 937, 946-48 (2002), aff'd by, 2002 FED App. 0291P (6th Cir.) (holding that blanket closure of deportation hearings in special interest cases is unconstitutional). For further discussion of the issues surrounding the closure of immigration hearings, see William Glaberson, Secret Trials: Closed Immigration Hearings Criticized as Prejudicial, N.Y. TIMES, Dec. 7, 2001, at B7; Todd S. Purdum, The Attorney General: Ashcroft's About-Face on the Detainees, N.Y. TIMES, Nov. 28, 2001, at B7.

$$
262387 \text { U.S. } 253 \text { (1967). }
$$


voluntarily, ${ }^{263}$ reversing its earlier decision in Perez v. Brownwell. ${ }^{264}$ Yet all of these cases lack the other elements that make Schneiderman a good candidate for the constitutional canon (its discussion of what it means to believe in the Constitution, and its use of various styles of reasoning, for example) and are somewhat less important in the area of immigration regulation. Schneiderman established an evidentiary burden that guides all cases of potential denaturalization, and thus has broad application, while other cases govern discrete situations. Schneiderman also led to a number of other holdings because of its recognition of the importance of citizenship, and therefore the difficulty that should exist in stripping such citizenship. Finally, Schneiderman was the first case to strike a real, decisive, and public blow in favor of immigrants' rights, and thus surely has a special status compared to later cases that merely built on Schneiderman's general concerns.

\section{The Theoretical Canon and Schneiderman}

Schneiderman can be considered a part of the academic theory canon. It is centrally important to have a theory of Schneiderman if you are to be taken seriously in several important academic debates. First, in the postSeptember 11 world, to be a participant in American academic constitutional discourse, you need the ability to discuss national identity, the role of courts during wartime, the "immigration Constitution," all of the issues discussed above in the context of cultural literacy. With the prominence of such issues in the public eye, these debates will inevitably surface in academic circles as well. ${ }^{265}$

The scholar who studies constitutional change must explain Schneiderman. Something must explain over two hundred years of a written constitution, one Civil War, two World Wars, a Cold War, the end of slavery, and less than thirty constitutional amendments. As scholars like Bruce Ackerman $^{266}$ and Stephen Griffin ${ }^{267}$ have argued, theories of constitutional law must explain constitutional change. Indeed, in many earlier editions of constitutional law casebooks, constitutional change was a central issue. In earlier editions of the Robert Eugene Cushman casebook, ${ }^{268}$ for instance,

${ }^{263} I d$. at 257 (holding that Congress has no "general power, express or implied, to take away an American's citizenship without his assent").

${ }^{264} 356$ U.S. 44 (1958).

${ }^{265}$ To a great degree, these debates have already surfaced. See supra notes 5-6.

${ }^{266} 1$ BRUCE A. ACKerman, We the PeOPle: Foundations 5 (1991) [Hereinafter 1 ACKerman]; 2 Bruce A. ACKerman, We the People: Transformations 7 (1998) [Hereinafter 2 ACKerman].

${ }^{267}$ STEPHEN GRIFFIN, AMERICAN CONSTITUTIONALISM: FrOM THEORY TO POLITICS 10 (1996).

${ }^{268}$ Robert Eugene Cushman, LeAding Constitutional DeCisions 1 (1933). 
the first topic was "Amendments to the Constitution," and the first case covered was Hawke v. Smith. ${ }^{269}$ While constitutional law casebooks now generally start with an examination of Marbury v. Madison, ${ }^{270}$ casebooks during the early part of the century more often focused on constitutional change. This is undoubtedly due to the interests of political scientists, who were much more central to the study of constitutional law than they are today, and who tended to focus more on constitutional change than law professors. This also may be due to a Continental style of thinking about constitutional law, which defines the structural features and rules of recognition in a Constitution.

In a country that continually wrestles with questions about identity and the constitution of the body politic, and is doing so more than ever before, there are good reasons to include Schneiderman in the theoretical canon. While Ackerman and Griffin focus on the mechanisms of constitutional change, Schneiderman asks one to consider how much constitutional change is too much. Ackerman and Griffin are more concerned, in other words, with the process of constitutional change, while Schneiderman is concerned with substantive limitations on constitutional change. This substantive element to discussions of constitutional change is a crucial aspect of understanding the key elements of American constitutionalism, and it has a long history. ${ }^{271}$ Before the federal Constitution, and in the Early Republic, there was substantial support for the notion that some parts of the Constitution simply could not be amended. Proponents of this view argued that such limitations were justified either as a matter of natural law or because some provisions of the Constitution were so central to the Constitution that the Constitution could not exist without them. This debate resulted in a substantial movement, led by Baltimore attorney William Marbury and Princeton professor Edward Corwin, to have courts recognize that Article V may not be the way to change fundamental constitutional provisions. Cases such as the National Prohibition Cases $^{272}$ rejected this view. Although the issue was raised during congressional hearings about a flag burning constitutional amendment, and is occasionally discussed in various pieces of scholarship, ${ }^{273}$ this whole saga is generally an underappreciated part of the theoretical canon. ${ }^{274}$

\footnotetext{
${ }^{269} 253$ U.S. 221 (1920) (finding that because Article V specifically confers upon state legislatures the power to ratify amendments when Congress proposes that mode of ratification - rather than ratification by state conventions - a state may not interfere with that allocation of power by permitting its citizens to override the state legislature's ratification decision by popular referendum).

${ }^{270} 5$ U.S. 137(1 Cranch) (1803).

${ }^{271}$ Bruce Ackerman, Constitutional Politics/Constitutional Law, 99 Yale L.J. 453, 457-61 (1989) (proposing a "revised three-solution narrative" for constitutional interpretation).

272253 U.S. 350, 386 (1920)

2731 ACKERMAN, supra note 266, at 15-16; LAURENCE H. TRIBE, AMERICAN CONSTITUTIONAL LAW 89-92, 110-17 (3d ed. 2000) (examining whether an amendment can be unconstitutional); see also Douglas Linder, What in the Constitution Cannot Be Amended, 23 ARIZ. L. REV. 717 (1981); Jeff Rosen, Was the Flag Burning Amendment Unconstitutional?, 100 YALE L.J. 1073 (1991).
} 
preciated part of the theoretical canon. ${ }^{274}$

At a broader level, this notion of substantive limitations on constitutional change implicates a more general issue, what I call "hierarchicalization" in American constitutional law. By this, I ask: What provisions of the United States Constitution are the most important? ${ }^{275}$ This question has been implicit in much of American constitutional scholarship. ${ }^{276}$ Yet Schneiderman poses the question in a unique and challenging way, and thus forces the concerned academic to test whatever theory they subscribe to all over again.

A theory of hierarchicalization is relevant for many issues in American constitutional law. Most obviously, constitutional provisions come into conflict all of the time, and lawyers, courts and scholars sometimes must resolve this conflict by deciding which constitutional provision is more important. The recent sovereign immunity jurisprudence has attempted to reconcile a potential clash between the Eleventh and Fourteenth Amendments. ${ }^{277}$ Recent religion cases illustrate a conflict between the Establishment and Free Exercise Clauses, ${ }^{278}$ and a case before the Court this term features a conflict between the Copyright Clause and the First Amendment. ${ }^{279}$ Cases and scholarship addressing this battle usually attempt to avoid the question of hierarchicalization and find other ways to resolve these issues, ${ }^{280}$ yet these issues are centrally important. Certainly, one of

${ }^{274}$ See Measures to Protect the Physical Integrity of the American Flag: Hearings on S. 1338, H.R. 2978, and S.J. Res. 180 Before the Comm. on the Judiciary, 101st Cong., 1st Sess. 536-39 (1989) (testimony of Prof. Walter Dellinger) (discussing the President's proposal for a constitutional amendment).

${ }^{275}$ James Madison spoke about certain "great rights [such as] the trial by jury, freedom of the press, ... [and] liberty of conscience.” Milton R. KOnVitz, Fundamental Rights: HistoRy of A CONSTITUTIONAL DOCTRINE 8 (2001).

${ }^{276}$ This question has been implicit in much of Carolene Products Footnote Four scholarship, for example. Footnote four stated that the key, fundamental aspect of the Constitution is its protection of minorities and their access to the political process. United States v. Carolene Prods., 304 U.S. 144, 152 n.4 (1938). This is more important, than, for instance, protecting an even balance between federal and state powers. Questions about what constitute a liberty interest under the Fourteenth Amendment are inevitably about what rights are considered to be the most fundamental.

${ }^{277}$ See, e.g., Seminole Tribe of Florida v. Florida, 517 U.S. 44, 59 (1996) ("[T] $]$ hrough the Fourteenth Amendment, federal power extend[s] to intrude upon the province of the Eleventh Amendment and therefore that $\S 5$ of the Fourteenth Amendment allow[s] Congress to abrogate the immunity from suit guaranteed by that Amendment").

${ }^{278}$ See, e.g., Rosenberger v. Rector \& Visitors of Univ. of Va., 515 U.S. 819, 845-46 (1995) (" $[\mathrm{T}] \mathrm{o}$ scan and interpret student publications to discern their underlying philosophic assumptions respecting religious theory and belief ... would risk fostering a pervasive bias or hostility to religion, which could undermine the very neutrality the Establishment Clause requires. There is no Establishment Clause violation in the University's honoring its duties under the Free Speech Clause.").

${ }^{279}$ Eldred v. Reno 239 F.3d 372 (D.C. Cir. Feb 16, 2001), cert. granted sub nom. Eldred v. Ashcroft 122 S. Ct. 1170 (2002) (examining a potential First Amendment problem with a congressional copyright law).

${ }^{280}$ One way of reconciling these tensions is to recognize a distinction between constitutional provisions granting powers and constitutional provisions limiting powers. In this age, with the death of 
many reasons that the Fourteenth Amendment can trump Eleventh Amendment sovereign immunity is not just because the Fourteenth Amendment came later, but also because it is a fundamental constitutional provision that is the result of a "constitutional moment." 281 What if the First Amendment came into irreconcilable conflict with the Twenty-Sixth Amendment? A persuasive argument could be made that the First Amendment would prevail, because the First Amendment is more important.

Schneiderman must also be explained by those studying a number of other important issues in constitutional law. Schneiderman discusses the various aspects of citizenship - how one becomes a citizen, when one can be stripped of their citizenship, and what beliefs one must have to become a citizen. ${ }^{282}$ At the same time, discussions about the meaning of citizenship have taken on new importance in American public life and will likely take on new importance in American constitutional scholarship as well. During wartime, countries always debate with greater exigency what it means to be a member of a particular body politic.

Citizenship is also a core issue behind much American constitutional history, theory and scholarship. One of the persistent myths surrounding the Constitution is that the Framers cared very little about the status and content of citizenship, a central issue in Schneiderman. Surprisingly, this myth has been most prominently associated with Alexander M. Bickel. ${ }^{283}$ Bickel argued that because the Preamble spoke of "We the People" rather than "We the Citizens," and because the Bill of Rights applied to all people, the Framers did not care all that much about citizenship and that "the original Constitution presented the edifying picture of a government not [concerned] with . . . some legal construct called citizenship." 284

Bickel does not take into account the importance that the notion of citizenship had within the general political philosophy of the Framers. The text of the Constitution in 1789 did not clearly define "citizen," yet citizenship is mentioned as a qualification for the presidency, and for membership in the House of Representatives and Senate. ${ }^{285}$ The Constitution also granted Congress the authority to establish a uniform rule of naturalization. ${ }^{286}$ The Comity Clause in the Constitution expanded upon the notion of citizenship by stating that "[t]he Citizens of each State shall be entitled

\footnotetext{
formalism, constitutional provisions granting powers can be interpreted extremely broadly, and thus this distinction might not matter all that much. The strategy often used in the sovereign immunity cases - that later in time prevails - is also frequently used to address this issue. E.g., Seminole Tribe v. Florida, 517 U.S. 44, 65 (1996); Fitzpatrick v. Baker, 427 U.S. 445, 545-55 (1976).

${ }^{281}$ This is Bruce Ackerman's phrase. 1 ACKERMAN, supra note 266, at 160.

${ }^{282}$ Schneiderman v. United States, 320 U.S. 118, 118 (1943)

${ }^{283}$ ALEXANDER M. BICKEL, THE MORALiTy OF CONSENT 36 (1975).

${ }^{284}$ Id.

${ }^{285}$ U.S. CONST. art. I, $\S 2$, cl.2; art. I, $\S 3$, cl. 3; art. II, $\S 1$, cl. 5.

${ }^{286}$ U.S. CONST. art. I, $\S 8$, cl. 4.
} 
to all Privileges and Immunities of Citizens in the several States." 287 The Articles of Confederation had included a provision which stated that "the free inhabitants of each ... State . . shall be entitled to all privileges and immunities of free citizens in the several States." 288 The change from the Articles language to the constitutional language was very important, as James Madison explained:

[Under the Articles of Confederation], [i]t seems to be a construction scarcely avoidable ... that those who come under the denomination of free inhabitants of a State, although not citizens of such State, are entitled, in every other State, to all the privileges of free citizens of the latter; that is, to greater privileges than they may be entitled to in their own State: so . . . every State is laid under a necessity not only to confer the rights of citizenship in other States upon any whom it may admit to such rights within itself, but upon any whom it may allow to become inhabitants within its jurisdiction. ${ }^{289}$

This reworking of the Comity Clause - plus the inclusion of the Naturalization Clause after no such clause was in the Articles-seems to indicate an understanding among the Founders that citizenship was important. Moreover, as crucial rights are linked to the legal status of citizenship, ${ }^{290}$ it

${ }^{287}$ U.S. CONST. art. IV, $\S 2$, cl. 1.

${ }^{288}$ ARTICLES OF CONFEDERATION CONST. art. IV (1777).

${ }^{289}$ THE FEDERALIST No. 42, at 270 (James Madison) (Clinton Rossiter ed., 1961).

${ }^{290}$ Then-Justice William H. Rehnquist has noted that citizenship is textually important in the Constitution because "in no less than 11 instances [is it mentioned] in a political document noted for its brevity." Sugarman v. Dougall, 413 U.S. 634, 651-52 (1973) (Rehnquist, J., dissenting). After all, the most important constitutional officer - the President of the United States - must be a "natural born Citizen." U.S. CONST. art. II, §1, cl. 5. Citizenship is also mandatory for certain types of federal court jurisdiction, U.S. CONST. art. III, $\S 2$, cl. 1, and even for access to certain voting rights. U.S. CONST. amends. XIV, § $2, \mathrm{XV}, \S 1$.

It is still true, however, that many elements of the Constitution do not recognize distinctions between citizens and non-citizens. The First and Fourth Amendments protect the rights of "the people." U.S. CONST. amend. I; U.S. CONST. amend. IV. The Fifth and Fourteenth Amendment Due Process Clauses, as well as the all-important Fourteenth Amendment Equal Protection Clause, apply to "person[s]." U.S. Const. amend. V; U.S. Const. amend. XIV, § 1. Rights regarding a criminal trial apply to "the accused." U.S. CONST. amend. VI.

Constitutional case law supports the notion that can be gleamed from the constitutional text that not all rights are dependent on citizenship. The Supreme Court has stated that the First and the Fifth Amendments do not contemplate "any distinction between citizens and resident aliens." Kwong Hai Chew v. Colding, 344 U.S. 590, 596 n.5 (1953) (interpreting immigration regulations permitting the exclusion of aliens on covert evidence not to apply to a permanent resident alien because of the potential constitutional concerns that such an interpretation would cause). The Court has also recognized that the Equal Protection Clause applies to almost everyone, regardless of nationality. Yick Wo. v. Hopkins, 118 U.S. 356, 369 (1886) (explaining that due process and equal protection apply to all people regardless of race, color, or nationality). The Court has held the same for the Due Process Clause. Zadvydas v. Davis, 533 U.S. 678 (2001) (finding that "the Due Process Clause applies to all "persons" within the United States, including aliens, whether their presence here is lawful, unlawful, temporary, or permanent"); see also Plyer v. Doe, 457 U.S. 202, 222 n.20 (explaining that although a non-citizen is 
is worth talking about, and more importantly, worth putting in a constitutional law casebook. Indeed, it is hard to imagine that at a time when Loyalist disaffection was a key issue in American politics, the drafters of the Constitution did not consider citizenship to be an important issue. ${ }^{291}$

Recent scholarship has picked up on the constitutional text focusing on citizenship, the Framers' preoccupation with citizenship, and the implications of citizenship for various legal questions. For instance, Kenneth Karst famously identified a norm of "equal citizenship" implicit in the Warren Court's Fourteenth Amendment cases. ${ }^{292}$ The notion of the importance of the content of citizenship has now received attention at the Supreme Court level. In Saenz v. Roe ${ }^{293}$ the Court invalidated a California law that cut the amount of welfare benefits payable to families residing in the state for less than a year to the (generally lower) amount that they would have received in their state of previous residence. Public policy, as well as the expressive nature of citizenship, ${ }^{294}$ also demonstrates the centrality of citizenship. ${ }^{295}$ Proposition $187^{296}$ and the 1996 Welfare Reform Act, ${ }^{297}$ for instance, purport to abolish many public benefits for noncitizens who reside in the United States.

Indeed, even beyond constitutional history, scholarship and doctrine, and general public policy, there is a strong case that immigration and naturalization law, two of the core elements of citizenship law, are the heart of liberal democratic constitutionalism. Citizenship laws distribute power and assign status among individuals, and indeed they "also literally constitute

not permitted to participate in the political process by voting or running for federal office, such a person may participate in other aspects of society); Mathews v. Diaz, 426 U.S. 67, 77 (1976) (deciding that the Due Process Clause applies to aliens whose presence in the country is "unlawful, involuntary or transitory").

${ }^{291}$ See KeTtNeR, supra note 217, at ch. 7 (1978) (discussing citizenship issues).

${ }^{292}$ Peter H. SChuck, Citizens, StRANGers and In-Betweens: Essays ON IMmigration AND CitizENSHIP 29-31, 176-78, 364-66 (1998) (conforming ideas of equal citizenship with trends in the Warren Court's decisions); Kenneth L. Karst, Foreword: Equal Citizenship Under the Fourteenth Amendment, 91 HARV. L. REV. 1, 21 (1977) (“[T]he [Warren] Court's decisions, in result and in reasoning, repeatedly confirm the emergence of the equal citizenship principle."); Charles L. Black, Jr., The Unfinished Business of the Warren Court, 46 WASH. L. REV. 3, 8-9 (1970) ("[W]e would be wrong not to see in the work of the Warren Court ... an affirmation . . . of the positive content and worth of American citizenship.").

${ }^{293} 526$ U.S. 489, 492, 494-95, 510-11 (1999).

${ }^{294}$ By this I mean that even if a citizen had no formal legal significance, it would still be a powerful statement of one's membership in a community.

${ }^{295}$ Supra discussion notes 266-70.

${ }^{296}$ Proposition 187, passed by California voters in 1994, denied health care, education and other various public services to undocumented immigrants. CAL. CODE $\S 48215$ (1) (West 1995). It required some social services employees to notify the government if they suspected that one of their clients was an undocumented immigrant. Id.

${ }^{297}$ Personal Responsibility and Work Opportunity Reconciliation Act of 1996, Pub. L. No. 104193, 110 Stat. 2105 (1996), amended by Pub. L. No. 104-302, 110 Stat. 3656 (1996). 
. . . a collective civic identity." ${ }^{298}$ Because citizenship is newly relevant and important in the post-September 11 world, was central to the founding, is central to American constitutional history, and is an important element of contemporary scholarly analysis of the Constitution, it is clearly a subject that any serious scholar of constitutional law must study. In addition, any study of citizenship must discuss Schneiderman, which is clearly a case about the content and obligations of American citizenship, and when citizenship can be stripped.

Recent social changes that make Schneiderman an indispensable part of the cultural literacy canon have also made it an indispensable part of the theoretical canon, as discussed above. Questions of national identity are of newfound interest, and are reflected in many of the citizenship discussions mentioned above, due to the increasingly diverse American republic. Multiculturalism has become a central point of concern of scholarship and law. The pioneering works of theorists such as Will Kymlicka, ${ }^{299}$ Charles Tay$\operatorname{lor}^{300}$ and Iris Young ${ }^{301}$ mark the beginning of the discussion about multiculturalism in the academy. Scholars must now confront multiculturalism in a new way: What impact does multiculturalism have on what it means to be an American? A case like Schneiderman poses this question in a critical way.

Finally, any scholar who wants to understand race and the Constitution must have some understanding and theory of the history of immigration law detailed in Schneiderman. There has long been an unfortunate-and quite surprising - gap between immigration scholars and critical race theorists, as has been pointed out by Kevin Johnson ${ }^{303}$ and others. ${ }^{304}$ For in-

\footnotetext{
${ }^{298}$ Rogers M. SMith, Civic IDEALS: CONFLICTING Visions OF CitIZENSHIP IN U.S. History 31

${ }^{299}$ Will Kymlicka, Multicultural Citizenship: A Liberal Theory of MinORity Rights 6,

300 Charles Taylor, Multiculturalism: Examining the Politics of Recognition 25 (Amy Gutmann ed., 1994).

${ }^{301}$ See IRIS MARION Young, Justice AND THE Politics OF DifFerenCe 14 (1990).

${ }^{303}$ Kevin R. Johnson, Race Matters: Immigration Law and Policy Scholarship, Law in the Ivory Tower, and the Legal Indifference of the Race Critique, 2000 U. ILL. L. REV. 525, 527 (2000). For responses to Johnson's argument, see, for example, Joan Fitzpatrick, Race, Immigration, and Legal Scholarship: A Response to Kevin Johnson, 2000 U. ILL. L. REV. 603 (2000); George A. Martinez, Race and Immigration Law: A Paradigm Shift, 2000 U. ILl. L. Rev. 517, 517-18 (2000); Michael A. Olivas, Immigration Law Teaching and Scholarship in the Ivory Tower: A Response to Race Matters, 2000 U. ILL. L. REV. 613, 613, 617 (2000).

${ }^{304}$ E.g., Stephen Shie-Wei Fan, Note, Immigration Law and the Promise of Critical Race Theory: Opening the Academy to the Voices of Aliens and Immigrants, 97 COLUM. L. REV. 1202 (1997).
} (1997). 9 (1995). 
stance, African and Caribbean immigration has received almost no attention from critical race scholars, who have instead concentrated on the constitutional history surrounding native-born Americans whose African heritage tends to be traced to ancestors arriving as captives of the slave trade several centuries ago. ${ }^{305}$ As has been discussed above, much of the racial content of the American population and the constitutional regulation of race have been implicated in American immigration history.

\section{CONCLUSION}

Schneiderman is an incredibly compelling and important case, one deserving of canonical status even before September 11. September 11, however, changed the way we think about many issues - foreign policy, national security, technology - and it should similarly change the way we study and think about American constitutional law. Including Schneiderman in the American constitutional canon is a perfect way to start to make this change. The case is interesting, exciting, well argued by the lawyers, examined extensively by the Justices, and makes for a wonderfully engaging subject of analysis. As an additional matter, it does all of this in the context of raising some fundamental issues relevant to all of the various types of canons mentioned by Balkin and Levinson. It is time to pull Schneiderman out of the hidden basement of constitutional law and teach it to American law students.

${ }^{305}$ The only possible exception to this trend is the greater attention given to Haitian immigrants. The situation of Haitian asylum seekers has been more visible in the legal literature than the plight of other recent migrants of African heritage. See Johnson, supra note 303, at 532 n.32, 544 n.94. (citing articles criticizing U.S. policy toward Haitian refugees and others linking the evolution of immigration law to the forced migration of slaves from Africa, resulting in treatment of immigrants as articles of commerce). There are some exceptions. E.g., Gabriel J. Chin, Segregation's Last Stronghold: Race Discrimination and the Constitutional Law of Immigration, 46 UCLA L. REV. 1 (1998); Berta Esperanza Hernandez-Truyol \& Kimberly A. Johns, Global Rights, Local Wrongs, and Legal Fixes: An International Human Rights Critique of Immigration and Welfare "Reform," 71 S. CAL. L. REV. 547, 549-50 (1998). 